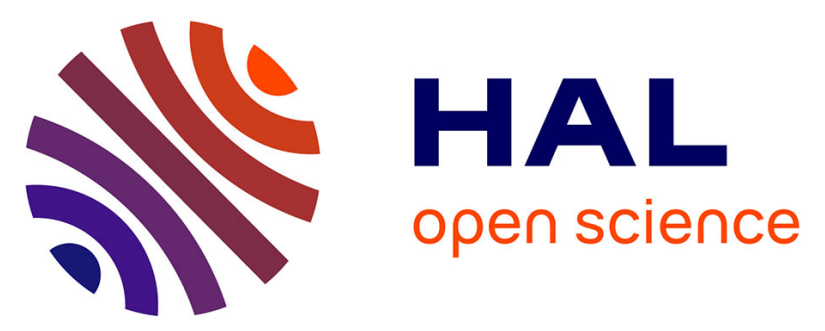

\title{
Exsolution of Ni Nanoparticles from A-Site-Deficient Layered Double Perovskites for Dry Reforming of Methane and as an Anode Material for a Solid Oxide Fuel Cell
}

\author{
Praveen B Managutti, Simon Tymen, Xiu Liu, Olivier Hernandez, Carmelo \\ Prestipino, Annie Le Gal La Salle, Paul Sébastien, Louise \\ Jalowiecki-Duhamel, Vincent Dorcet, Alain Billard, et al.
}

\section{- To cite this version:}

Praveen B Managutti, Simon Tymen, Xiu Liu, Olivier Hernandez, Carmelo Prestipino, et al.. Exsolution of Ni Nanoparticles from A-Site-Deficient Layered Double Perovskites for Dry Reforming of Methane and as an Anode Material for a Solid Oxide Fuel Cell. ACS Applied Materials \& Interfaces, 2021, 13 (30), pp.35719-35728. 10.1021/acsami.1c08158 . hal-03333672

\section{HAL Id: hal-03333672 \\ https://hal.science/hal-03333672}

Submitted on 7 Oct 2021

HAL is a multi-disciplinary open access archive for the deposit and dissemination of scientific research documents, whether they are published or not. The documents may come from teaching and research institutions in France or abroad, or from public or private research centers.
L'archive ouverte pluridisciplinaire HAL, est destinée au dépôt et à la diffusion de documents scientifiques de niveau recherche, publiés ou non, émanant des établissements d'enseignement et de recherche français ou étrangers, des laboratoires publics ou privés. 


\title{
Exsolution of Ni nanoparticles from $A$-site deficient layered double perovskites for dry reforming of methane and as anode material for solid oxide fuel cell
}

Praveen B. Managutti, Simon Tymen ${ }^{\mathrm{b}}$, Xiu Liu ${ }^{\mathrm{c}}$, Olivier Hernandez ${ }^{\mathrm{a}}$, Carmelo Prestipino ${ }^{\mathrm{a}}$, Annie Le Gal La Salle ${ }^{\mathrm{b}}$, Sébastien Paul ${ }^{\mathrm{c}}$, Louise Jalowiecki-Duhamel ${ }^{\mathrm{c}}$, Vincent Dorcet ${ }^{\mathrm{a}}$, Alain Billard $^{\mathrm{d}}$, Pascal Briois ${ }^{\mathrm{d}}$ and Mona Bahout*a

${ }^{a}$ Univ. Rennes, CNRS, ISCR (Institut des Sciences Chimiques de Rennes) - UMR 6226, F35000 Rennes, France

${ }^{\mathrm{b}}$ Institut des Matériaux Jean Rouxel (IMN), CNRS UMR 6502, Université de Nantes, 2 rue de la Houssinière, B.P. 32229 Nantes Cedex 3, France

${ }^{\mathrm{c}}$ Univ. Lille, CNRS, Centrale Lille, Univ. Artois, UMR 8181 - UCCS - Unité de Catalyse et Chimie du Solide, F-59000 Lille, France

${ }^{\mathrm{d}}$ FEMTO-ST Institute (UMR CNRS 6174), Univ. Bourgogne Franche-Comté, UTBM, 2 Place Lucien Tharradin, F-25200 Montbéliard Cedex, France.

\begin{abstract}
Metallic nanoparticles structured layered perovskite oxides prepared by the in situ exsolution method are widely utilized as alternative anodes for solid oxide fuel cells. In this work, Nidoped perovskite $\left(\operatorname{Pr}_{0.5} \mathrm{Ba}_{0.5}\right)_{1-x / 2} \mathrm{Mn}_{1-x / 2} \mathrm{Ni}_{x / 2} \mathrm{O}_{3-\delta}(S-\mathrm{PBMNx} x=0,0.05,0.1$ and 0.2$)$ are prepared to design nanostructured layered perovskites $(R-\mathrm{PBMNx})$ for electrochemistry and catalysis applications. X-ray diffraction and TEM analysis demonstrate that combining $A$-site deficiency and $\mathrm{Ni}$-doping can effectively promote the exsolution of $\mathrm{Ni}$ nanoparticles. However, on heating the reduced/exsolved materials in air at $800{ }^{\circ} \mathrm{C}$, the $\mathrm{Ni}$ nanoparticles oxidize to $\mathrm{NiO}$ on the layered perovskite surface instead of dissolving into the host lattice.
\end{abstract}


The lowest Area Specific Resistance, $A S R$ in a symmetrical cell in wet $5 \% \mathrm{H}_{2} / \mathrm{N}_{2}$ atmosphere is obtained for $R$-PBMN0.2 ( $A S R \sim 0.64 \Omega \mathrm{cm}^{2}$ at $850{ }^{\circ} \mathrm{C}$ ) is ascribed to the highest exsolved $\mathrm{Ni}$ amount. The best performance for dry reforming of methane (DRM) was also obtained for $R$-PBMN0.2 with $\mathrm{CH}_{4}$ and $\mathrm{CO}_{2}$ conversion rates at $11 \%$ and $32 \%$, respectively along with the highest $\mathrm{H}_{2}$ production rate $(37 \%)$, while no activity was detected for $R$-PBMN0. The DRM performance of $R$-PBMN0.2 was sustained at $800{ }^{\circ} \mathrm{C}$ for up to at least $5 \mathrm{~h}$ operation with little carbon deposition $\left(0.017\right.$ g. gcat $\left.^{-1} \mathrm{~h}^{-1}\right)$.

These results demonstrate that varying Ni-doping in the parent perovskite oxide is an effective strategy to manipulate the electrochemical performance of SOCs' hydrogen electrode and catalytic activity of ceramic oxides for energy conversion applications.

Keywords: nanoparticles exsolution, layered perovskite, manganite, solid oxide fuel cell, anode, dry reforming of methane, impedance spectroscopy, fuel electrode, catalysis.

\section{Introduction}

Solid-oxide fuel cells (SOFCs) are among the most attractive energy conversion systems due to their high efficiency, low pollution emission, and good fuel flexibility. ${ }^{1}$ However, their high operating temperatures $\left(800-1000{ }^{\circ} \mathrm{C}\right)$ result in high degradation and manufacturing costs, preventing large-scale commercialization of this technology. ${ }^{2}$ Typical SOFCs employ nickelbased cermet anodes, which exhibit good mechanic and chemical compatibility with the traditional stabilized zirconia or doped ceria electrolytes. Nickel is an excellent catalyst for hydrogen oxidation but suffers redox instability and coarsening. In addition Ni/YSZ exhibits unsatisfactory performance during operation with methane due to carbon deposition from cracking $\left(\mathrm{CH}_{4}=\mathrm{C}+2 \mathrm{H}_{2}\right)$ and sulfur poisoning ${ }^{3}$ blocking the reaction of the catalyst sites. Interesting alternative materials to $\mathrm{Ni} / \mathrm{YSZ}$ cermet anodes are mixed ionic and electronic 
conducting (MIEC) oxides among which the $A$-site layered ordered perovskites, $L n \mathrm{BaMn}_{2} \mathrm{O}_{5+\delta}$ with $L n=\mathrm{Pr}, \mathrm{Nd}$, have been identified as potential candidates because of their redox stability and reduced sensitivity to sulfur-containing fuel impurities. ${ }^{4-6}$ However, their electrochemical performance under hydrogen and hydrocarbon fuels is poor. ${ }^{7}$ The electrochemical performance of ceramic anodes can be improved by adding a small amount of electrocatalyst nanoparticles (NPs) by impregnating the MIEC oxide with a metallic salt or a suspension of metallic nanoparticles. ${ }^{8-10}$ However, these techniques generally result in weak bonding between the NPs and the support ${ }^{11}$ that often leads to coarsening of the Ni catalyst particles during cell processing or during the cell tests. ${ }^{12}$ In addition, impregnation is a multisstep process difficult to scale-up for large cells. To overcome the difficulties of the conventional deposition methods, the alternative exsolution or solid-phase crystallization process, well-known in reforming catalysis ${ }^{13-20}$ has been proposed to improve the (electro)catalytic activity of fuel electrodes..$^{21,22}$ In the exsolution approach, the electrocatalyst element $\left(\right.$ e.g., $\left.\mathrm{Ni}^{2+}\right)$ is introduced into the chemical composition during the synthesis in air and then in situ released in reducing conditions $\left(\mathrm{H}_{2}\right.$ atmosphere, electric potential) as fine metal NPs dispersed on the oxide support. ${ }^{15,23}$ It has been shown that the catalysts prepared by exsolution are more resistant to agglomeration and sintering (loss of active surface area) a s well as to sulfides poisoning and carbon deposition (blocking of active sites) due to the strong interaction of the nanoparticles with the support. ${ }^{24}$ While exsolution has largely been investigated for $\mathrm{ABO}_{3}$ perovskites, transition metals exsolution on the surface of layered perovskites has been much less documented. Recently, Kwon et al. investigated the exsolution trends of various transition metals $(T=\mathrm{Mn}, \mathrm{Co}, \mathrm{Ni}, \mathrm{Fe}$ and $\mathrm{Mo})$ on $\operatorname{PrBaMn}_{1.7} T_{0.3} \mathrm{O}_{5}{ }^{25}$ and evaluated the impact of the exsolved nanocatalysts on the SOFCs' anode performance and for hydrocarbon reforming. ${ }^{26,13,25,27}$ For example, $\operatorname{PrBaMn}_{1.7} \mathrm{Co}_{0.3} \mathrm{O}_{5}$ 
enables almost twice higher power density under humidified $\mathrm{H}_{2}$ than $\operatorname{PrBaMn}_{2} \mathrm{O}_{5}, P_{\max } \sim 1.15$ versus $\sim 0.68 \mathrm{Wcm}^{-2}$ at $800{ }^{\circ} \mathrm{C}^{25}$

It has been shown that $A$-site deficiency in $A B \mathrm{O}_{3}$ perovskites can promote exsolution and catalytic activity. ${ }^{28-31}$ In the layered double perovskite family, apart from two recent reports on iron-based compositions ${ }^{27,}{ }^{32}$, all the exsolution studies relate to stoichiometric compositions with $A / B=1$. In the present work, $A$-site deficiency has been introduced in $(\mathrm{PrBa})_{1-\mathrm{x} / 2} \mathrm{Mn}_{2-\mathrm{x}} \mathrm{Ni}_{\mathrm{x}} \mathrm{O}_{6-\delta}$ to facilitate exsolution. In addition, it has been correlated to the Nicontent $^{16,33}$ to prevent structural instability ( $B$-site vacancies) or formation of secondary phases $\left(\mathrm{BaO}\right.$ and $\left.\operatorname{Pr}_{2} \mathrm{O}_{3}\right)$. The exsolution process was examined by thermogravimetric analysis (TGA), X-ray diffraction (XRD) and, scanning and transmission electron microscopy (SEM/TEM). The reduced materials were tested under wet $5 \% \mathrm{H}_{2} / \mathrm{Ar}$ by electrochemical impedance spectroscopy (EIS) in 8YSZ electrolyte supported symmetrical cells to assess the influence of $\mathrm{Ni}$ exsolution on the area specific resistance, $A S R$.

Because Ni catalyst is a viable industrial option for dry reforming of methane (DRM) ${ }^{34-46}$, the exsolved layered double perovskites have been tested for the DRM process illustrated by equation (1):

$$
\mathrm{CH}_{4}+\mathrm{CO}_{2} \rightleftharpoons 2 \mathrm{H}_{2}+2 \mathrm{CO} \quad \Delta \mathrm{H}^{\mathrm{o}}{ }_{298}=247 \mathrm{~kJ} / \mathrm{mol}
$$

In Ni-based catalysts, $\mathrm{Ni}$ is prone to deactivation by sintering ${ }^{47}$ and carbon deposition, illustrated by Eqs. (2)-(5) ${ }^{46}$ :

$$
\begin{array}{ll}
2 \mathrm{CO} \rightarrow \mathrm{CO}_{2}+\mathrm{C} & \Delta H^{0}{ }_{298 \mathrm{~K}}=-171 \mathrm{~kJ} \mathrm{~mol}^{-1} \\
\mathrm{CH}_{4} \rightarrow 2 \mathrm{H}_{2}+\mathrm{C} & \Delta H^{0}{ }_{298 \mathrm{~K}}=+76 \mathrm{~kJ} \mathrm{~mol}^{-1} \\
\mathrm{CO}_{2}+2 \mathrm{H}_{2} \rightarrow \mathrm{C}+2 \mathrm{H}_{2} \mathrm{O} & \Delta H^{0}{ }_{298 \mathrm{~K}}=-90 \mathrm{~kJ} \mathrm{~mol}^{-1} \\
\mathrm{CO}+\mathrm{H}_{2} \rightarrow \mathrm{C}+\mathrm{H}_{2} \mathrm{O} & \Delta H^{0}{ }_{298 \mathrm{~K}}=-131 \mathrm{~kJ} \mathrm{~mol}^{-1}
\end{array}
$$


In addition to coking issue, the reverse water gas shift reaction (RWGS, Eq. 6) that occurs simultaneously ${ }^{48,49}$ to the DRM process shifts the $\mathrm{H}_{2} / \mathrm{CO}$ ratio of the DRM reaction below unity : $\mathrm{CO}_{2}+\mathrm{H}_{2} \rightarrow \mathrm{CO}+\mathrm{H}_{2} \mathrm{O} \quad(\mathrm{RWGS}) \quad \Delta H^{0}{ }_{298 \mathrm{~K}}=+41 \mathrm{~kJ} \mathrm{~mol}^{-1}$

Il faut que je rajoute une phrase de transition avant de commencer le prochain paragraphe

\section{Experimental}

\section{Synthesis}

Polycrystalline samples of nominal compositions $\left(\mathrm{Pr}_{0.5} \mathrm{Ba}_{0.5}\right)_{1-\mathrm{x} / 2} \mathrm{Mn}_{1-\mathrm{x} / 2} \mathrm{Ni}_{\mathrm{x} / 2} \mathrm{O}_{3-\delta}$ with $x=0$, $0.05,0.1$ and 0.2 were synthesized by the citrate-nitrate sol-gel process. Stoichiometric amounts of $\operatorname{Pr}\left(\mathrm{NO}_{3}\right)_{2} \cdot 6 \mathrm{H}_{2} \mathrm{O}$ (Aldrich, 99.9\%), $\mathrm{Ba}\left(\mathrm{NO}_{3}\right)_{2}$ (Aldrich, 99\%), $\mathrm{Mn}\left(\mathrm{NO}_{3}\right)_{2} \cdot 4 \mathrm{H}_{2} \mathrm{O}$ (Aldrich, 98\%), $\mathrm{Ni}\left(\mathrm{NO}_{3}\right)_{2} \cdot 6 \mathrm{H}_{2} \mathrm{O}$ (Aldrich, $98.5 \%$ ) were dissolved in aqueous solution under stirring. Citric acid (CA, Fisher Scientific) and ethylene glycol (EG, Fisher Scientific) were added to the metal nitrates. The molar ratio of CA and EG to total metal ions was $3: 1.5: 1$. The $\mathrm{pH}$ value of the solution was adjusted to $\sim 8$ by adding ammonium hydroxide to enhance cation binding to the citrate and avoid the precipitation of individual hydroxides. ${ }^{50}$ The solution was continuously stirred on the hot plate at $80^{\circ} \mathrm{C}$ and slowly evaporated and the resulting resin was subsequently calcined at $550{ }^{\circ} \mathrm{C}$ overnight. The solid precursor was ground and pressed in dense pellets (10 $\mathrm{mm}$ diameter, 2-3 $\mathrm{mm}$ thickness) which were annealed in air at $950{ }^{\circ} \mathrm{C}$ for $24 \mathrm{~h}$ to give the perovskite samples, $S$-PBMNx ( $S$ for synthesized).

\section{Reduced/exsolved samples.}

The $S$-PBMNx pellets were heated under humidified $5 \% \mathrm{H}_{2} / \mathrm{Ar}\left(3 \% \mathrm{H}_{2} \mathrm{O}\right)$ at $T \sim 875{ }^{\circ} \mathrm{C}$ for $18 \mathrm{~h}$ to form the layered perovskites while exsolving the Ni particles as confirmed by XRD and electron microscopy. Hereafter, the reduced (exsolved) samples are referred as $R$-PBMNx ( $R$ for reduced). 


\section{Material characterization}

Powder X-ray diffraction (XRD) patterns are measured on a Bruker AXS D8 Advance diffractometer in Bragg-Brentano geometry equipped with Ge a (111) Johansson focusing primary monochromator $\left(\mathrm{Cu}-\mathrm{K}_{\alpha 1}\right)$ and a silicon strip Lynxeye detector. Data were analyzed by the Rietveld method with the FullProf program ${ }^{51}$. The oxygen content $(5+\delta)$ was determined by iodometric titration against a standardized sodium thiosulfate solution according to a procedure reported elsewhere. ${ }^{4,5}$ Thermogravimetric analyses (TGA) (Netzsch STA $449 \mathrm{~F} 3$ instrument) were performed under $5 \% \mathrm{H}_{2} / \mathrm{N}_{2}\left(40 \mathrm{~mL} \mathrm{~min}{ }^{-1}\right)$ from 20 to $1000{ }^{\circ} \mathrm{C}$ at a heating/cooling rate of $10{ }^{\circ} \mathrm{C} \min ^{-1}$ to characterize the thermophysical properties. The surface morphology was studied by scanning electron microscopy (SEM) using a JEOL JSM $7100 \mathrm{~F}$ microscope. The microstructure and element distribution were probed by Scanning Transmission Electron Microscopy (STEM) using a JEOL $2100 \mathrm{LaB}_{6}$ instrument operating at $200 \mathrm{kV}$ equipped with an Energy Dispersive X-ray Spectroscopy (EDS) detector (OXFORD $\left.\mathrm{X}-\mathrm{MAX}^{\mathrm{N}} 80 \mathrm{~T}\right)$. For TEM measurements, the powder samples were crushed in dry ethanol and a droplet of the suspension was mounted on a carbon-coated copper grid.

\section{Cell fabrication}

Symmetrical cells composed of dense 8YSZ (8\% yttria-stabilized zirconia TOSOH, $500 \mu \mathrm{m}-$ thick) and porous $R$-PBMNx were fabricated for electrochemical impedance spectroscopy (EIS) measurements. To prevent ionic interdiffusion, a $\mathrm{Ce}_{0.9} \mathrm{Gd}_{0.1} \mathrm{O}_{1.95}(\mathrm{CGO})^{6,52}$ buffer layer $(500 \mathrm{~nm})$ was applied on both sides of the electrolyte by physical vapor deposition. ${ }^{53}$ The experimental device is a 100-litre Alcatel SCM 650 sputtering chamber pumped down via a system combining XDS35i Dry Pump and a 5401CP turbo-molecular pump. The sputtering chamber is equipped with three $200 \mathrm{~mm}$ diameter magnetron targets and with a $620 \mathrm{~mm}$ 
diameter rotating substrate holder parallel to the targets at about $110 \mathrm{~mm}$. The distance between the target's axis and that of the substrate holder is $170 \mathrm{~mm}$. The 10 at. \% Gd-Ce target is supplied thanks to a pulsed DC Advanced Energy dual generator allowing the control of the discharge current, power, or voltage. The deposition stage is monitored by a closed loop control Plasma Emission Monitoring system using optical emission spectroscopy. In the present study, the discharge current is fixed at $2.5 \mathrm{~A}$ and the total pressure is $\sim 0.2 \mathrm{~Pa}$. Further details were reported elsewhere (ref Pascal, Braez?). The electrode slurry was prepared by mixing 60 wt.\% of $R$-PBMNx powder with 40 wt.\% of $\alpha$-terpineol (99\% Acros Organics) /ethyl cellulose (Aldrich) $(95 / 5 \mathrm{w} / \mathrm{w})$. The mixture was ground with ethanol in a planetary ball mill and subsequently screen-printed on both sides of the CGO/8YSZ electrolyte and sintered in air at $1100{ }^{\circ} \mathrm{C}$ for $3 \mathrm{~h}$. Circular gold meshes were fixed to both electrode surfaces and connected to the external system The effective electrode area was $0.95 \mathrm{~cm}^{2}$ and its thickness was estimated at $\sim 30 \mu \mathrm{m}$ from cross-section SEM-images.

\section{Electrochemical measurements}

The cell was placed into the open-flange setup TM provided by the Swiss company Fiaxell described previously. ${ }^{21}$ The temperature was measured by a thermocouple close to the electrode surface. EIS was measured in potentiostatic mode with a VersaSTAT device and associated VersaStudio software in the frequency range of $0.01-10,000 \mathrm{~Hz}$ in a temperature range of $850{ }^{\circ} \mathrm{C}$ to $650{ }^{\circ} \mathrm{C}$, at open circuit voltage (OCV) conditions with an $\mathrm{AC}$ voltage amplitude of $\sim 10 \mathrm{mV}$ which ensures the best signal to noise ratio without loss of the transfer function. ${ }^{54,55}$ The cell was heated in air to $T \sim 600{ }^{\circ} \mathrm{C}$ and then wet $5 \% \mathrm{H}_{2} / \mathrm{Ar}\left(3 \% \mathrm{H}_{2} \mathrm{O}\right)$ was supplied with a flow rate of $\sim 200 \mathrm{mLmin}^{-1}$ while the temperature was increased to $T \sim 850$ ${ }^{\circ} \mathrm{C}$. Before starting the measurements, the cell was maintained at $850{ }^{\circ} \mathrm{C}$ until a steady state was achieved (15 - $24 \mathrm{~h})$. The electrochemical impedance was measured from $850{ }^{\circ} \mathrm{C}$ to 650 
${ }^{\circ} \mathrm{C}$ at $50{ }^{\circ} \mathrm{C}$ intervals. The data were analyzed by the ZView ${ }^{\circledR}$ software (D. Johnson, ZView:

A software program for EIS analysis (Version 2.8, Scribner associates, INC, Southern Pines, NC, 2002). 


\section{Catalytic activity tests}

The specific surface area of the reduced catalyst was determined from $\mathrm{N}_{2}$ adsorption and desorption isotherms results by the Brunauer-Emmett-Teller (BET) method in a volumetric apparatus ensuring a vacuum of at least $10^{-5} \mathrm{~mm} \mathrm{Hg}$. The specific surface areas of the $R$ PBMNx samples are $\sim 10 \mathrm{~m}^{2} \mathrm{~g}^{-1}$, which is similar to related perovskites. ${ }^{42}$ The catalytic activity for DRM was evaluated at atmospheric pressure by a gas chromatography instrument (TRACE GC ULTRA) equipped with a thermal conductivity detector (TCD) and a flame ionization detector (FID). The $S$-PBMNx powder sample $(\sim 50 \mathrm{mg})$ was deposited on a frit in the middle of a fixed bed "up flow" quartz tube reactor (inner diameter $8 \mathrm{~mm}$ ). The reaction temperature was measured by A K-type thermocouple fixed at the center of the catalyst bed. The sample was in situ reduced under hydrogen flow at $800{ }^{\circ} \mathrm{C}$ for $10 \mathrm{~h}$. After reduction, the quartz tube was purged with $\mathrm{N}_{2}$ gas for $1 \mathrm{~h}$ to remove residual $\mathrm{H}_{2}$, and then $\mathrm{CH}_{4}, \mathrm{CO}_{2}$, and $\mathrm{N}_{2}$ were introduced in 3:3:94 molar ratio at a volumetric flow rate of $80 \mathrm{mLmin}^{-1}$ corresponding to a gas hourly space velocity (GHSV) of $96,000 \mathrm{mLg}_{\text {cat }}{ }^{-1} \mathrm{~h}^{-1}$.

The catalytic performance was assessed through online analyses of the feed and product outlet gases under steady-state conditions. The $\mathrm{CH}_{4}$ and $\mathrm{CO}_{2}$ conversion $\left(X_{\mathrm{CH} 4}, X_{\mathrm{CO} 2}\right)$, the molar composition of products $\left(C_{\mathrm{i}}\right)$ on n'utilise pas, $\mathrm{CO}$ selectivity, and $\mathrm{H}_{2} / \mathrm{CO}$ molar ratio are calculated as follow:

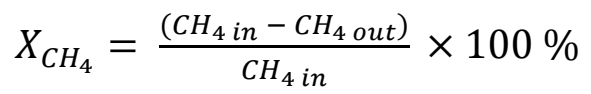

$$
\begin{aligned}
& X_{\mathrm{CO}_{2}}=\frac{\left(\mathrm{CO}_{2 \text { in }}-\mathrm{CO}_{2 \text { out }}\right)}{\mathrm{CO}_{2 \text { in }}} \times 100 \% \\
& C_{i}=\frac{n_{i}}{\sum \text { productsn }_{i}} \times 100 \% \\
& C O_{\text {selectivity }}=\frac{\mathrm{CO}_{\text {out }}}{\mathrm{CO}_{\text {out }}+\mathrm{CO}_{2} \text { out }} \times 100 \%
\end{aligned}
$$

$\mathrm{H}_{2} / \mathrm{CO}$ ratio $=F_{\mathrm{H}_{2}}^{\text {out }} / F_{\mathrm{CO}}^{\text {out }}$

where $F_{H_{2}}^{\text {out }}$ and $F_{C O}^{\text {out }}$ are the effluent flow rates. 
Carbon formation was evaluated by TGA analysis in air.

\section{Results and discussion}

\section{Structure and microstructure characterization}

The crystalline structures of the oxide materials before and after reduction were examined by X-Ray diffraction (XRD) and scanning and transmission electron microscopy (SEM/TEM). As shown in Fig. S1, the diffraction patterns of the samples synthesized in air at $950{ }^{\circ} \mathrm{C}$ correspond to a mixture of orthorhombic (O, Space Group, S. G. Ibmm) and hexagonal (H, S.G. $\left.P 6_{3} / m m c\right) A B \mathrm{O}_{3}$ perovskite phases. The nickel dissolves into the perovskite structure at least up to $x=0.1$ but in the $S$-PBMN0.2, a small peak at $2 \theta \sim 43.36^{\circ}$ assigned to the $\left(\begin{array}{lll}2 & 0 & 0\end{array}\right)$ reflection of $\mathrm{NiO}$ (S.G. Fm-3m) suggests that the solubility limit of nickel is below $x=0.2$. From Rietveld refinements phase analysis, the solubility of nickel in $\left(\operatorname{Pr}_{0.5} \mathrm{Ba}_{0.5}\right)_{1-\mathrm{x} / 2} \mathrm{Mn}_{1 \text { - }}$ ${ }_{\mathrm{x} / 2} \mathrm{Ni}_{\mathrm{x} / 2} \mathrm{O}_{3-\delta}$ was evaluated at $x \sim 0.18$, which is below the $x \sim 0.3$ value reported for the $A$-site stoichiometric compositions. ${ }^{25}$ Annealing the $x=0.2$ sample at $1200{ }^{\circ} \mathrm{C}$ did not enable to dissolve all $\mathrm{NiO}$ into the perovskite lattice. Because high temperature annealing may cause nickel sublimation, the heat treatment at $950{ }^{\circ} \mathrm{C}-24 \mathrm{~h}$ was adopted.

The $S$-PBMNx pellets were reduced under humidified $5 \% \mathrm{H}_{2} / \mathrm{Ar}\left(3 \% \mathrm{H}_{2} \mathrm{O}\right)$ at $T \sim 875{ }^{\circ} \mathrm{C}$ for $18 \mathrm{~h}$ to exsolve the Ni particles. These conditions were selected from the TGA (Fig. S2) and in situ neutron diffraction ${ }^{21}$, enable nickel exsolution meanwhile the orthorhombic and hexagonal phases merge into a layered double perovskite phase-Therefore, the reduction of $S$ PBMNx correspond to the following reaction:

$$
\begin{array}{cc}
\left(\mathrm{Pr}_{0.5} \mathrm{Ba}_{0.5}\right)_{1-\mathrm{x} / 2} \mathrm{Mn}_{1-\mathrm{x} / 2} \mathrm{Ni}_{\mathrm{x} / 2} \mathrm{O}_{3-\delta} & \rightarrow(1-x / 2) \mathrm{PrBaMn}_{2} \mathrm{O}_{5}+x \mathrm{Ni} \\
\text { simple perovskites } & \text { layered double perovskite }
\end{array}
$$


Indeed, the XRD patterns of the reduced samples (Fig. 1), referred hereafter as $R$-PBMNx, reveal a main layered phase (S.G. P4/nmm) with a minor Ni phase (S.G. Fm-3m) suggested by the $\left(\begin{array}{lll}1 & 1 & 1\end{array}\right)$ reflection at $2 \theta \sim 44.45^{\circ}$ (JCPDS card \# 01-078-07533).

The refined $a$ and $c$ lattice parameters of the layered phase in the Ni-doped samples are the same as for $R$-PBMN0, $a=5.62337(3) \AA, c=7.76619$ (1) $\AA$ meaning that all nickel was exsolved according to Eq. (1). The nickel fraction refined at 0.64(4), 1.29(2) and 2.66(2) wt\% for the $R$-PBMNx samples with $x=0.05,0.1$ and 0.2 respectively as expected from total nickel exsolution. This situation differs from the $A$-site stoichiometric $\operatorname{PrBaMn}_{1.7} \mathrm{Ni}_{0.3} \mathrm{O}_{5+\delta}$ composition for which $58 \%$ of $\mathrm{Ni}$ was exsolved and can relate to difference in $A$-site content. $^{25}$ The average size of $\mathrm{Ni}$ particles in $R$-PBMNx of $\sim 40 \mathrm{~nm}$ calculated from the Scherrer equation ${ }^{56}$ is consistent with TEM images.

In undoped $R$-PBMN0 and low doped $R$-PBMN0.05 compositions, we noticed an extra peak at $2 \theta \sim 35^{\circ}$ (Fig. 1) assigned to (1 11 1) $\mathrm{MnO}$ reflection (JCPDS card \# 07-0230) in consistency with previous reports. ${ }^{57} 4,25$

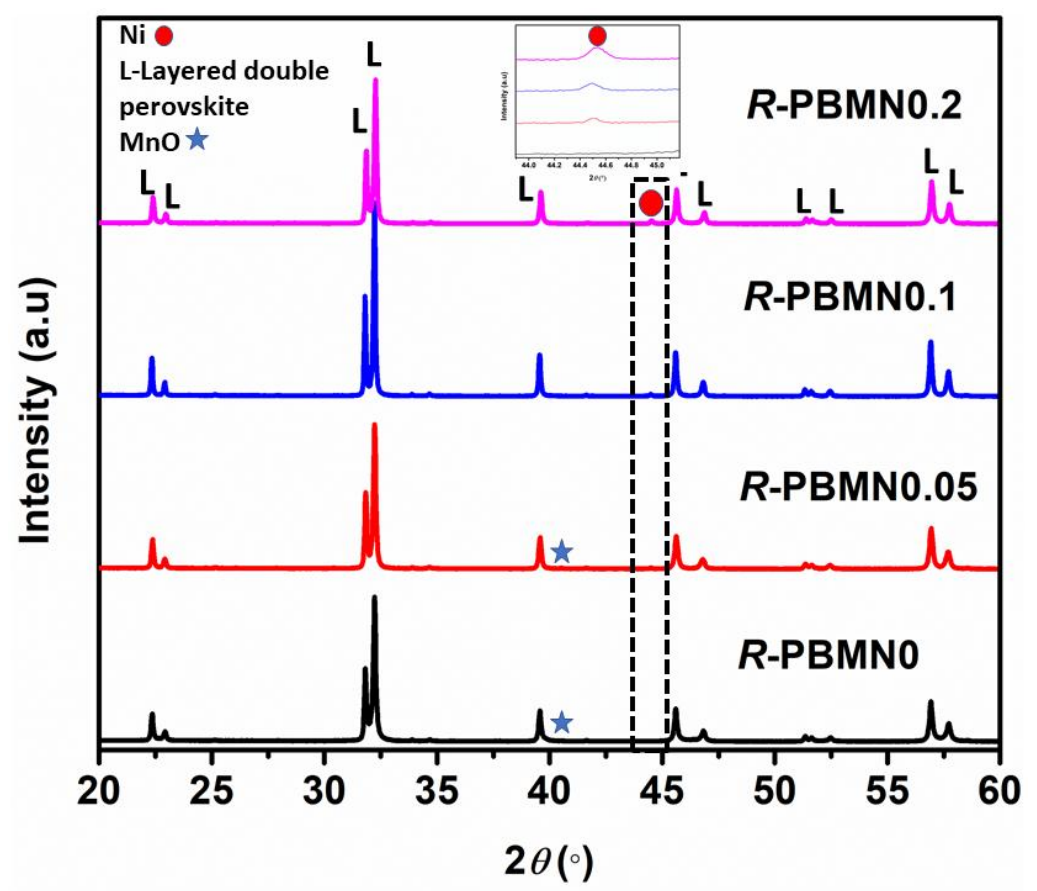

Figure 1. XRD of the $R$-PBMNx samples. The main Ni peak (111) is highlighted in the insert. MnO (111) reflection at $2 \theta \sim 40.5^{\circ}$ is labeled (*). 
To assess the exsolution process, the morphology of synthesized $(S$-PBMNx) and reduced $(R-$ PBMNx) samples was examined by SEM/TEM, as illustrated in Fig. 2 for $S$-PBMN0.1 and $R$ PBMN0.1. The typical grain size of both materials approaches $300 \mathrm{~nm}$. The surface of $S$ PBMN0.1 is smooth without any detectable NPs (Fig. 2a) whereas few nanoparticles (NPs) of $\sim 40 \mathrm{~nm}$ cover the surface of $R$-PBMN0.1 (Fig. $2 \mathrm{~b}$ ).
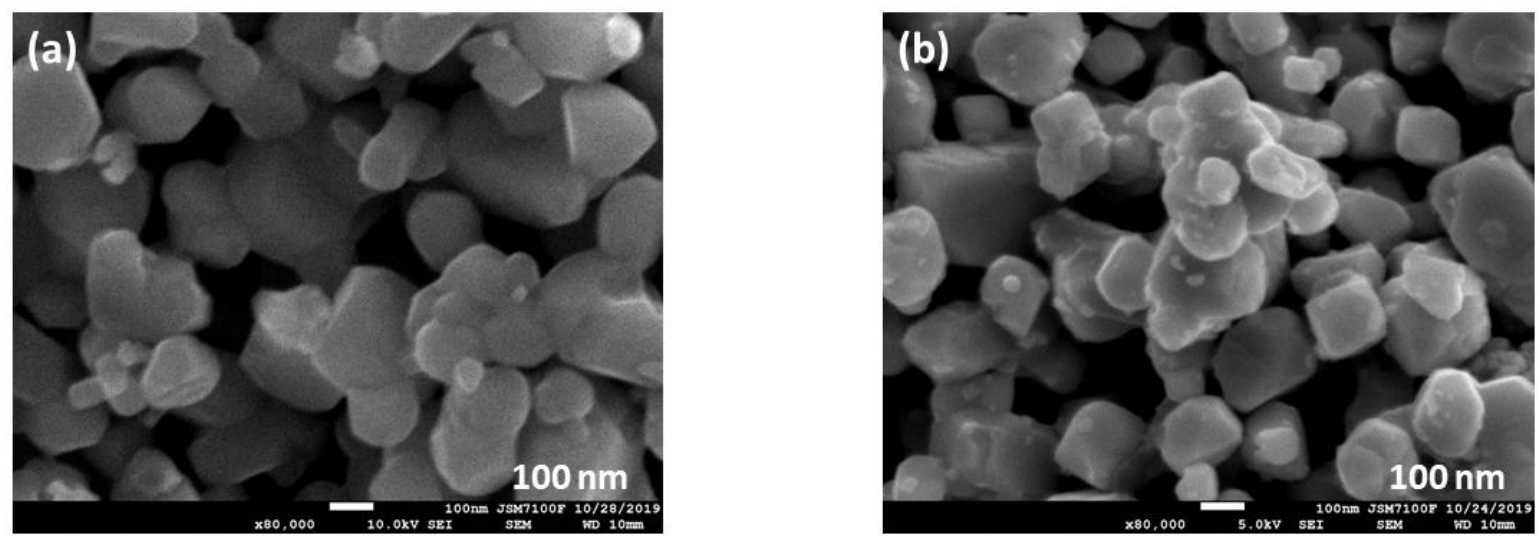

Figure 2. SEM images of (a) $S$-PBMN0.1 and (b) R-PBMN0.1.

Further information on the exsolved nanoparticles is obtained from high-resolution transmission electron microscopy (HRTEM) and energy dispersive X-ray spectroscopy (EDS). Figs. 3a shows two crystallized NPs socketed on the oxide support of R-PBMN0.1. Based on elemental mapping (Figs. 3c-g) and TEM-EDS analysis (Fig. S3), it comes back that the NPs consist of only nickel while the oxide support is nickel-free. Similar features were obtained for $R$-PBMN0.0 $5^{21}$ and $R$-PBMN0.2 (Fig. S4).

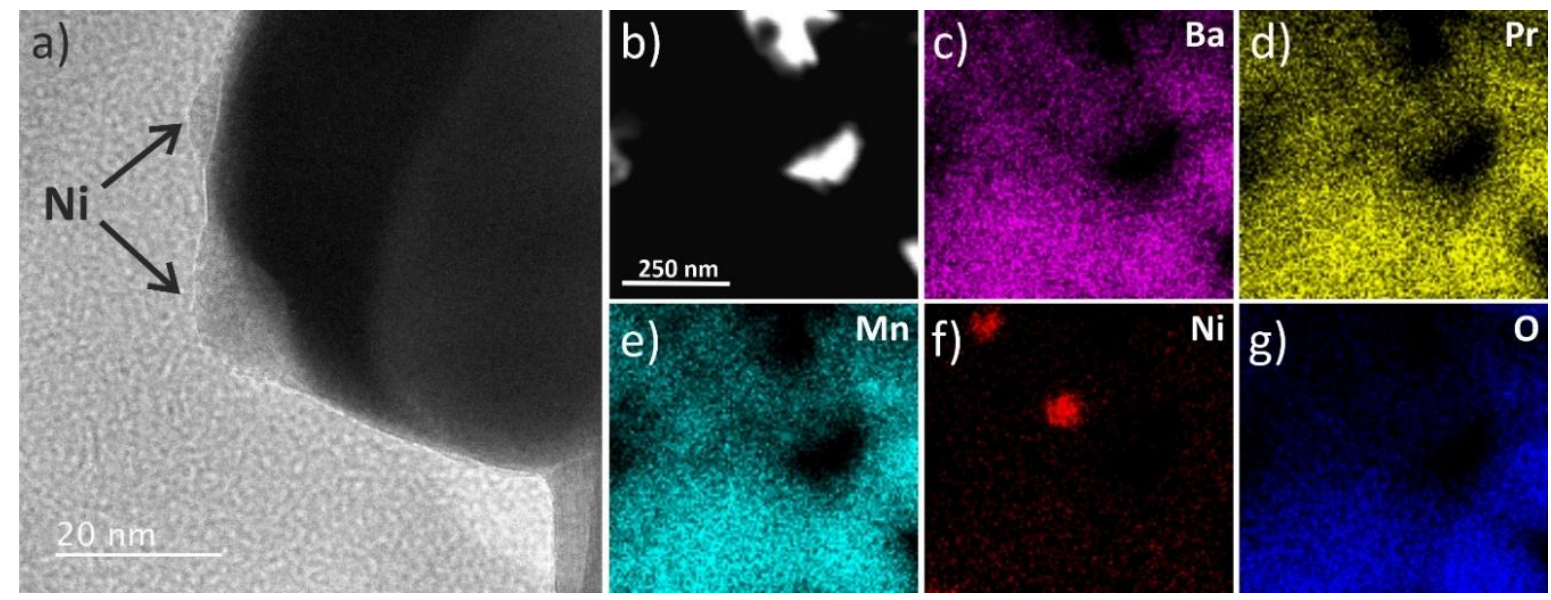


Figure 3. R-PBMN0.1: (a) HRTEM highlighting 2 nanoparticles on the oxide support, (b) Bright field image, and (c-g) STEM-EDS elemental mapping images.

It may happen that the exsolved particles dissolve back into the perovskite oxide under oxidizing conditions. In such a case, the metal catalyst and the dissolved ion can be cycled by switching between $\mathrm{H}_{2}$ and air. Such a reversible behavior, referred as "intelligent" catalysts can mitigate sintering issues of metal particles. ${ }^{58,59}$ For instance, in $\mathrm{La}_{0.3} \mathrm{Sr}_{0.7} \mathrm{Cr}_{0.3} \mathrm{Fe}_{0.6} \mathrm{Co}_{0.1} \mathrm{O}_{3}$, the NPs were completely reincorporated into the oxide host following oxidation in air at 800 ${ }^{\circ} \mathrm{C}$. ${ }^{60}$ To check the redox behavior of exsolution in the layered perovskite manganites, the $R$ PBMNx samples were heated in air at $800{ }^{\circ} \mathrm{C}$ overnight. The XRD patterns of the oxidized samples exhibit the (111) and (200) $\mathrm{NiO}$ reflections at $2 \theta \sim 37.1$ and $43.3^{\circ}$ (JCPDS card \#22$1189)$ as shown for the sample with the lowest nickel amount (O-PBMN5) in Fig. 4.

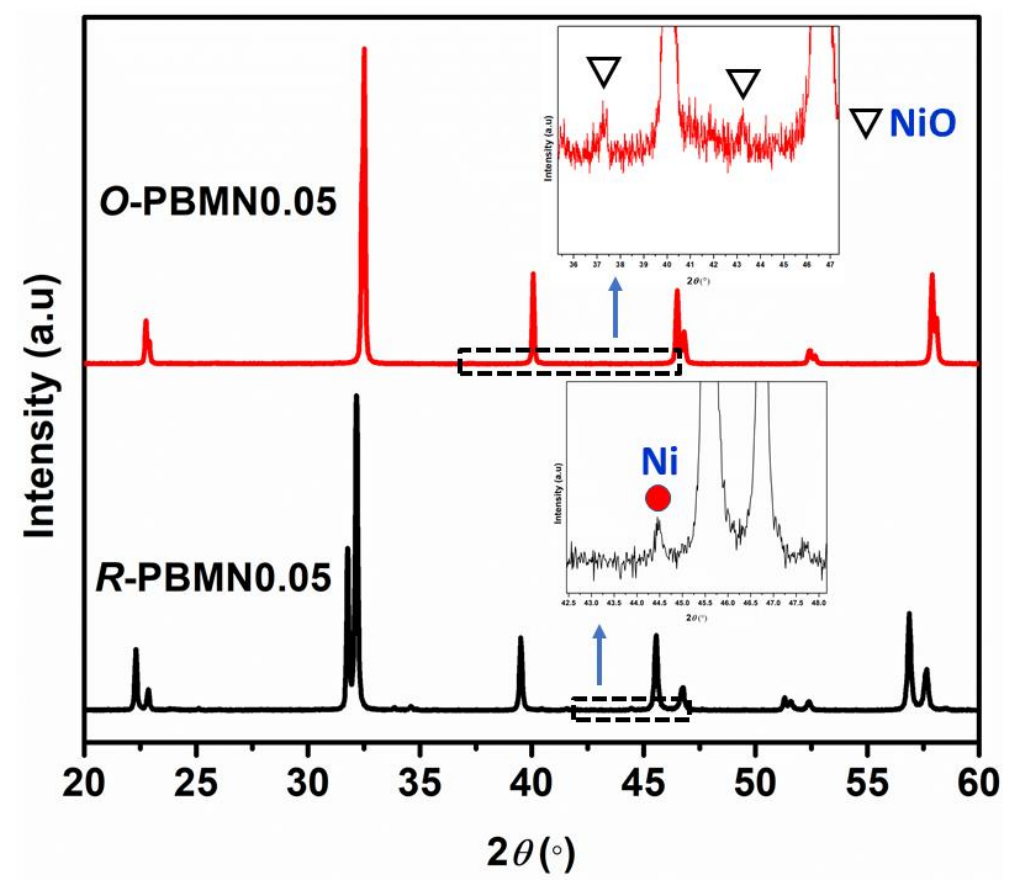

Figure 4. XRD of the reduced ( $R$-PBMN0.05) and oxidized $(O$-PBMN0.05) samples highlighting the oxidation of $\mathrm{Ni}$ to $\mathrm{NiO}$.

Furthermore, the PBMN0.05 samples were analysed by TEM after different heat treatments; i) air-annealing (S-PBMN0.05), ii) hydrogen reduction ( $R$-PBMN0.05) and, iii) subsequent 
reoxidation (O-PBMN0.05). TEM-EDS line spectrum of several $R$-PBMN0.05 and $O$ PBMN0.05 crystallites revealed an absence of Ni content in contrast to the general trend in $S$ PBMN0.05 (Fig. S5). These observations demonstrate that nickel which was completely exsolved from the perovskite backbone was unable to be restored to the host lattice. Since $0.05 \mathrm{Ni}$ did not dissolve in a $\mathrm{PrBaMn}_{2} \mathrm{O}_{5}$ formula unit (f.u.), dissolution of 0.1 and $0.2 \mathrm{Ni} / \mathrm{f} . \mathrm{u}$. is more challenging as revealed by the XRDs of $O$-PBMN0.1 and $O$-PBMN0.2 samples heated in air at $800{ }^{\circ} \mathrm{C}$ (Fig. S6). This exsolution irreversibility could be explained by two reasons; first because the $\operatorname{PrBaMn}_{2} \mathrm{O}_{5}$ host structure is stable due of to lack of $B$-site vacancies and, second because $\mathrm{PrBaMn}_{2} \mathrm{O}_{5}$ does not easily form substitution solid solution with $\mathrm{NiO}$ in contrast to cobalt and iron oxides. ${ }^{61-64}$ Though it sis the first time that redox exsolution irreversibility is been reported in layered double perovskite manganites, it has occurred in titanates perovskites such as $\mathrm{La}_{0.8} \mathrm{Ce}_{0.1} \mathrm{Ni}_{0.4} \mathrm{Ti}_{0.6} \mathrm{O}_{3}$ and $\mathrm{La}_{0.7} \mathrm{Ce}_{0.1} \mathrm{Co}_{0.3} \mathrm{Ni}_{0.1} \mathrm{Ti}_{0.6} \mathrm{O}_{3}$ and has explained by better lattice stability following $B$-site exsolution. ${ }^{14}$

\section{Chemical compatibility with the electrolytes}

To test the stability of the electrode materials with the electrolytes, 50/50 wt. \% mixtures of $R$-PBMNx and 8YSZ or CGO powders were pressed into pellets and heated in conventional electrode annealing conditions i.e., in air at $1100{ }^{\circ} \mathrm{C}$ for $3 \mathrm{~h}$. With CGO, the XRD after annealing shows any additional peaks indicating chemical compatibility of the electrode and the electrolyte components. Subsequent heating at the anode operating conditions in wet 5\% $\mathrm{H}_{2} / \mathrm{N}_{2}\left(3 \% \mathrm{H}_{2} \mathrm{O}\right)$ at $800{ }^{\circ} \mathrm{C}$ for $48 \mathrm{~h}$ suggested the absence of reactivity (Fig. S7a).

Conversely, with $8 \mathrm{YSZ}$ the powder mixtures heated in air at $1100{ }^{\circ} \mathrm{C}$ gave the $\mathrm{BaZrO}_{3}$ byproduct due to $\mathrm{Sr}$ and $\mathrm{Zr}$ diffusion. When the samples were subsequently heated in wet $5 \%$ $\mathrm{H}_{2} / \mathrm{Ar}$ at $800{ }^{\circ} \mathrm{C}$ for $48 \mathrm{~h}$, the barium zirconate impurity remains (Fig. S7b). The chemical reactivity of the related $\mathrm{NdBaMn}_{2} \mathrm{O}_{5}$ electrode material and YSZ has been reported 
previously. ${ }^{6}$ Due to chemical reactivity between our electrode materials and 8YSZ, a thin CGO buffer layer $(1 \mu \mathrm{m}$ thick) was deposited on both sides of the 8 YSZ electrolyte before screen printing the $R$-PBMNx electrode materials.

\section{Cell fabrication}

The electrode slurry was prepared by mixing $60 \mathrm{wt} . \%$ of $R$-PBMNx powder with $40 \mathrm{wt} . \%$ of $\alpha$-terpineol (99\% Acros Organics) /ethyl cellulose (Aldrich) $(95 / 5 \mathrm{w} / \mathrm{w})$. The ball milled mixture with ethanol was screen-printed on both sides of the CGO/8YSZ electrolyte and sintered in air at $1100{ }^{\circ} \mathrm{C}$ for $3 \mathrm{~h}$. Circular gold meshes were fixed to both electrode surfaces as interconnectors and attached to the external system The effective area of the electrode was $0.95 \mathrm{~cm}^{2}$ and the thickness was estimated at $\sim 30 \mu \mathrm{m}$ from cross-section SEM-images showing uniform porous structures and good adhesion to the CGO/8YSZ electrolytes (Fig. S8).

\section{Electrochemical measurements}

The cell was placed into the open-flange setup TM provided by the Swiss company Fiaxell described previously. ${ }^{21}$ The temperature was measured by a thermocouple close to the electrode surface. EIS was measured in potentiostatic mode with a VersaSTAT device and associated VersaStudio software in the frequency range of $0.01-10,000 \mathrm{~Hz}$ in a temperature range of $850{ }^{\circ} \mathrm{C}$ to $650{ }^{\circ} \mathrm{C}$ at open circuit voltage (OCV) conditions with an $\mathrm{AC}$ voltage amplitude of $\sim 10 \mathrm{mV}$ which ensures the best signal to noise ratio without loss of the transfer function. ${ }^{54,55}$ The cell was heated in air to $T \sim 600{ }^{\circ} \mathrm{C}$ and then wet $5 \% \mathrm{H}_{2} / \mathrm{Ar}\left(3 \% \mathrm{H}_{2} \mathrm{O}\right)$ was supplied with a flow rate of $\sim 200 \mathrm{mLmin}^{-1}$ while the temperature was increased to $T \sim 850$ ${ }^{\circ} \mathrm{C}$. The cell was maintained at $850{ }^{\circ} \mathrm{C}$ until a steady state was achieved $(15-24 \mathrm{~h})$. The 
electrochemical impedance was measured at $50{ }^{\circ} \mathrm{C}$ intervals from $850{ }^{\circ} \mathrm{C}$ to $650{ }^{\circ} \mathrm{C}$. The data were analyzed by the ZView® software.

\section{Electrochemical characterization of symmetric cells under wet hydrogen}

The purpose here is to evaluate the impact of $\mathrm{Ni}$ exsolution on the overall performance. Indeed, the processing parameters of the electrode materials were the same, hence the change in electrochemical performance is ascribed to the variation in $\mathrm{Ni}$ content. The impedance spectra of $R$-PBMN0, $R$-PBMN0.5 and $R$-PBMN0.2 obtained at $700{ }^{\circ} \mathrm{C}$ are shown in Fig. 5 .

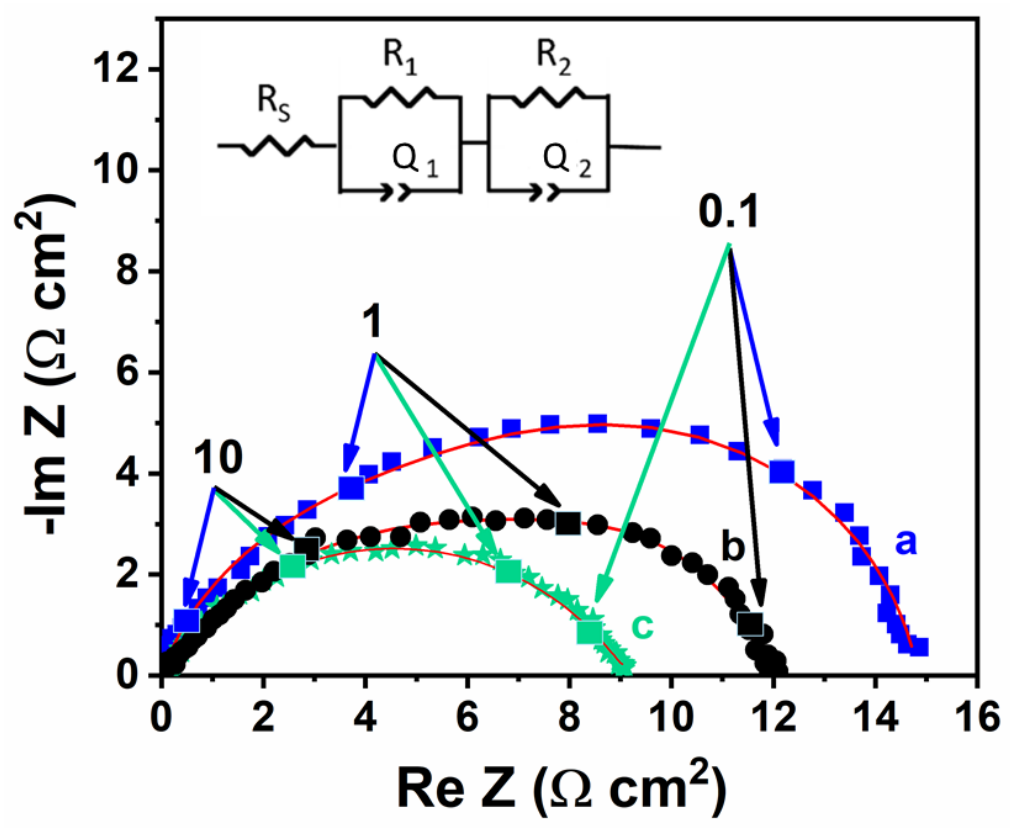

Figure 5. Nyquist impedance diagrams at $700{ }^{\circ} \mathrm{C}$ under wet $5 \% \mathrm{H}_{2}-95 \% \mathrm{Ar}\left(3 \% \mathrm{H}_{2} \mathrm{O}\right)$ at $\mathrm{OCV}$ for (a) $R$-PMBNO, (b) $R$-PMBN0.05 and (c) $R$-PMBN0.2 symmetrical cells on CGO/8YSZ electrolyte. To emphasize the anodic part of the impedance response, $R_{s}$ was subtracted. The numbers are the frequency.

In impedance spectra of symmetrical cells for the $\mathrm{H}_{2}$ oxidation reaction, ${ }^{65}$ two or three arcs (rate-limiting contributions) are generally observed in the frequency range of $10^{6}-0.05 \mathrm{~Hz}$. In the case of $R$-PBMNx symmetrical electrodes, two main components were considered and the data were fitted to the equivalent circuit $L R_{\mathrm{S}}(R Q)_{1}(R Q)_{2}$ following the circuit description 
codes of Boukamp. ${ }^{66}$ The inductance, $L$, is primarily ascribed to the leads, and a typical value is $1.5 \times 10^{-7} \mathrm{H}$ for the present measurement system. The series resistance, $R_{\mathrm{S}}$, is mainly ascribed to the electrolyte. Each parallel $(R Q)$ corresponds physically to one process occurring in the complex electrode reactions; $R$ is the corresponding resistance, and $Q$ is the Constant Phase Element (CPE) coefficient. $Q$ is related to the electrical impedance, $Z$, by equation:

$$
Z(\omega)=\frac{1}{Q(j 2 \pi f)^{n}}
$$

where $j$ is an imaginary unit, $f$ is the frequency, and $n(0 \leq n \leq 1)$ is the $C P E$ exponent. The capacitance, $C$, is calculated from $(R C)^{n}=R Q \cdot{ }^{67,68}$ The case $n=1$ describes an ideal capacitor while the case $n=0$ describes a pure resistor. The fitted parameters $(R, Z, n)$ or derived parameters $\left[\left(e . g ., f_{\max }, \mathrm{C}\left(f_{\max }\right)\right]\right.$ for each arc help identify the related process.

\section{Ni-free electrode, $R-P B M N O$}

Under our experimental conditions, the Ni-free anode, $R$-PBMN0 shows larger polarization resistance (curve a) than the Ni-exsolved anodes (curves b and c).

The impedance diagram of $R$-PBMN0 is split into two main contributions; at middle frequency $(M F: 1-10 \mathrm{~Hz})$ and low frequency $(L F: 1-0.1 \mathrm{~Hz})$. The corresponding resistance and capacitance calculated at different temperatures are listed in Table 1.

Table 1. Equivalent resistance and capacitance for $R$-PMBMNO in wet $\left(3 \% \mathrm{H}_{2} \mathrm{O}\right) 5 \% \mathrm{H}_{2} / \mathrm{Ar}$.

\begin{tabular}{|c|c|c|c|c|c|}
\hline $\boldsymbol{T}\left({ }^{\circ} \mathbf{C}\right)$ & 850 & 800 & 750 & 700 & 650 \\
\hline$R_{M F}\left(\Omega \mathrm{cm}^{2}\right)$ & 1.7 & 4.7 & 4.8 & 5.7 & 9.0 \\
\hline$C_{M F}\left(\mu \mathrm{F} \mathrm{cm}{ }^{-2}\right)$ & 470 & 360 & 320 & 340 & 210 \\
\hline$R_{L F}\left(\Omega \mathrm{cm}^{2}\right)$ & 1.1 & 1.7 & 4.3 & 9.1 & 22.8 \\
\hline$C_{L F}\left(\mathrm{mF} \mathrm{cm}^{-2}\right)$ & 2.6 & 3.3 & 1.4 & 2.5 & 2.4 \\
\hline
\end{tabular}

With capacitance values of $\sim 210-470 \mu \mathrm{F} \mathrm{cm} \mathrm{cm}^{-2}$, the $M F$ contribution can be attributed to oxygen ions $\left(\mathrm{O}^{2}\right)$ bulk diffusion, charge transfer and surface diffusion while the $L F$ contribution with higher capacitance of $\sim 3 \mathrm{mF} \mathrm{cm}^{-2}$ can be associated with hydrogen 
adsorption, dissociation and ionisation at the surface of the porous electrode. ${ }^{69-73}$ Arrhenius plots of $R_{M F}$ and $R_{L F}$ (Fig. 6) are consistent with thermally activated processes with $E_{a}\left(R_{M F}\right) \sim$ $1.5(1) \mathrm{eV}$ and $E_{a}\left(R_{L F}\right) \sim 1.7 \mathrm{eV}$. It can clearly be seen that the $L F$ contribution is the ratelimiting step at $T \leq 750{ }^{\circ} \mathrm{C}$, but this trend is reversed at $T>750{ }^{\circ} \mathrm{C}$. The activation energies are high compared with $E_{\mathrm{a}}\left(R_{L F}\right)$ values of- $0.5-0.8 \mathrm{eV}$ obtained for metal exsolved $\mathrm{Sr}_{2} \mathrm{Fe}_{1.5}(\mathrm{Mo}, \mathrm{Ni})_{0.5} \mathrm{O}_{6}$ anodes ${ }^{74}$ but similar to those obtained for $\mathrm{La}_{0.4} \mathrm{Sr}_{0.6} \mathrm{Ti}_{1-\mathrm{x}} \mathrm{MnO}_{3}$ anodes under similar conditions, $E_{a} \sim 1.5(1) \mathrm{eV} .^{75}$

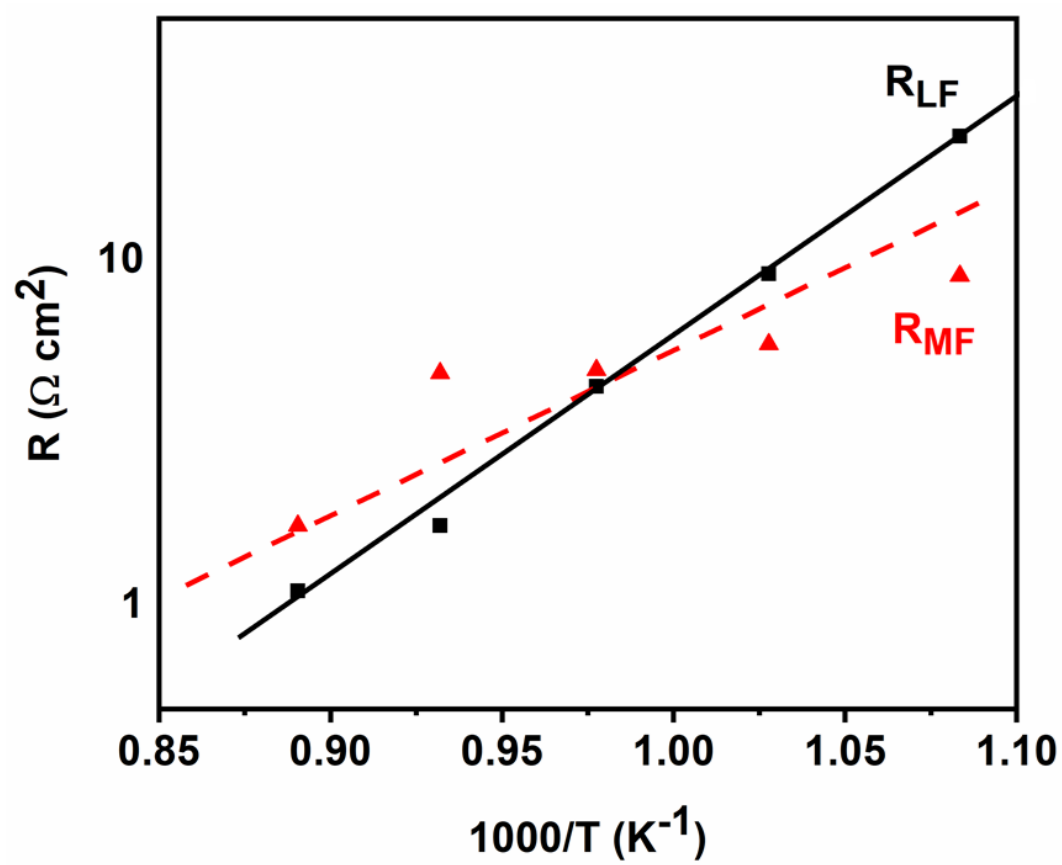

Figure 6. Temperature variation of $R_{M F}$ and $R_{L F}$ for $R$-PBMNO under wet $\left(3 \% \mathbf{H}_{2} \mathrm{O}\right) 5 \% \mathbf{H}_{2}-95$ $\%$ Ar at OCV. mettre les temperatures en haut.

i) Ni-exsolved electrodes, $R-P B M N x$

As for $R$-PBMN0, the impedance diagrams were fitted by two main components. The difference with $R$-PBMN0 is that the $M F$ contribution becomes invisible in the Ni-metal exsolved anodes and has been replaced by a component at higher frequency $(H F: 100-1 \mathrm{~Hz}$. However, the $L F$ contribution $(1-0.1 \mathrm{~Hz})$ is still present, as observed on Fig. 7. Such changes mean that the process at middle frequency is no more a rate-limiting step in the Ni-doped electrodes. This is consistent with the attribution of the $M F$ component to hydrogen 
adsorption, dissociation, and ionization process which has been accelerated by the metal NPs in the Ni-exsolved electrodes.

The presence of Ni-metal exsolved particles on the anode surface impacts the overall polarization resistance. For instance at $700{ }^{\circ} \mathrm{C}$, the $R_{p}$ value of $\sim 16 \Omega \mathrm{cm}^{2}$ obtained for $R$ PBMN0, has decreased to $\sim 12 \Omega \mathrm{cm}^{2}$ in $R$-PBMN0.05 and $\sim 9 \Omega \mathrm{cm}^{2}$ in $R$-PBMN0.2 (Fig. 5). Fig. 7 compares the Arrhenius plots of $R_{L F}$ for $R$-PBMN0 and Ni-doped electrodes. Although $R_{L F}$ has decreased with increased $\mathrm{Ni}$-content, the activation energy is insensitive to Nicontent. This statement agrees with the attribution of the $L F$ component to the oxygen exchange reaction on the electrode surface and/or to bulk diffusion of oxygen ions $\left(\mathrm{O}^{2}\right)$ into the electrode whose mechanism is not affected by the presence of the NPs.

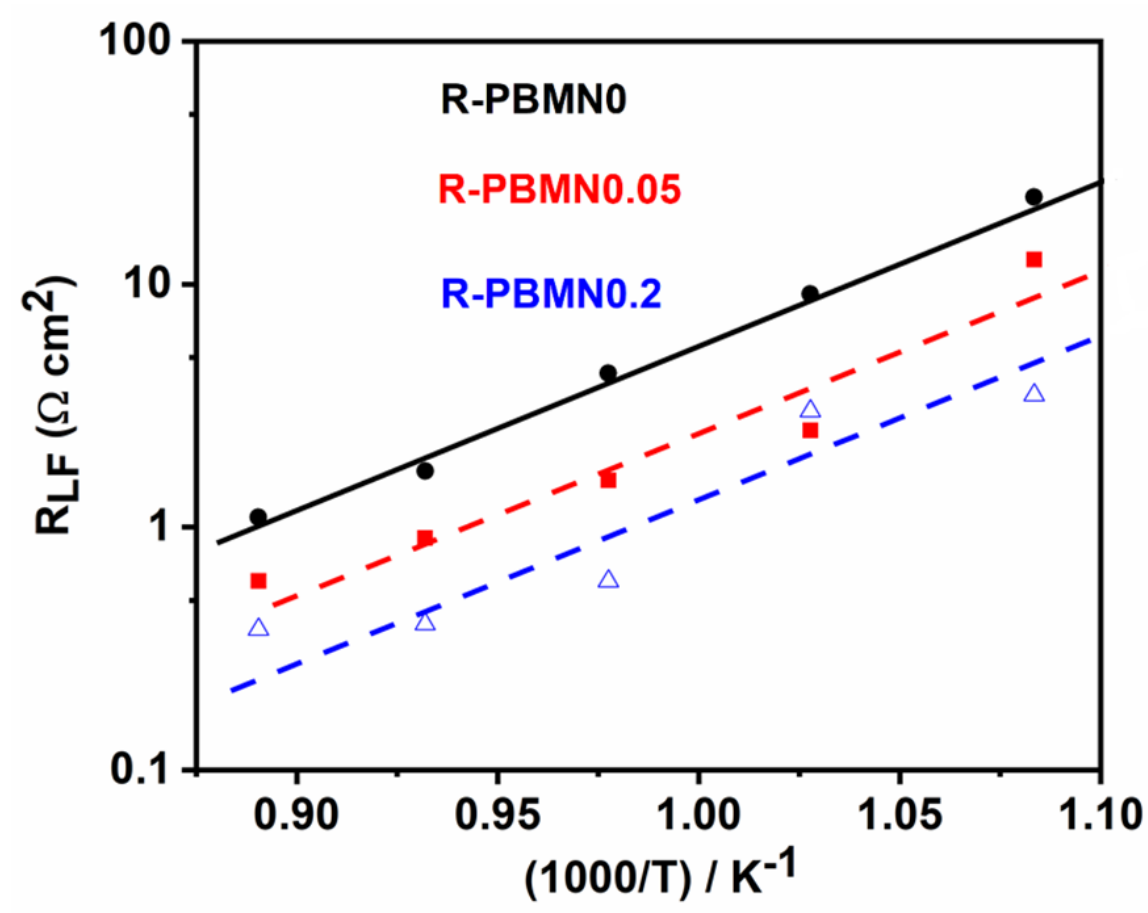

Figure 7. Arrhenius plots of $R_{L F}$ under wet $\left(3 \% \mathrm{H}_{2} \mathrm{O}\right) 5 \% \mathrm{H}_{2}-95 \% \mathrm{Ar}$.

Arrhenius plot of the Area Specific Resistance $\left(A S R=1 / 2 R_{p}\right)$ displayed in Fig. 8 show that the best performance is obtained for $R$-PBMN0.2 although the activation energy depends little on Ni-content. Since the Ni particle size $(\sim 40 \mathrm{~nm})$ is insensitive to Ni-content but depend on 
strain energy during nucleation, ${ }^{76}$ the best performance obtained for the $R$-PBMN0.2 anode might be associated with to the largest population of NPs and available sites for the electrochemical reaction.

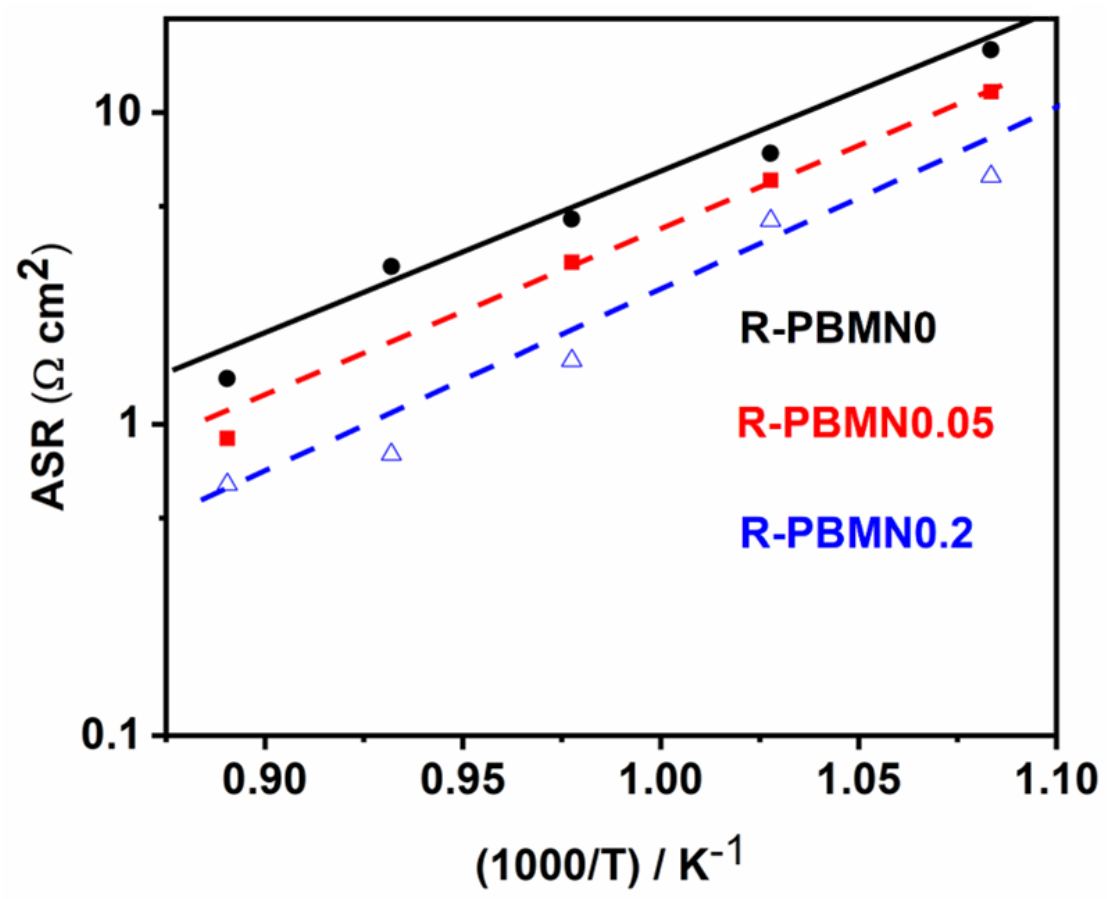

Figure 8. Arrhenius plots of $A S R$ under wet $\left(3 \% \mathrm{H}_{2} \mathrm{O}\right) 5 \% \mathrm{H}_{2}-95 \% \mathrm{Ar}$.

To summarize, $\mathrm{Ni}$ exsolution improves the overall electrochemical reaction rate as reflected by the decrease of the ASR. To meet the specific requirements of SOFC electrodes, the ASR should be $<0.1 \Omega . \mathrm{cm}^{2}$. The values reported here under $5 \% \mathrm{H}_{2} / \mathrm{N}_{2}$ atmosphere could be much lowered under realistic operating conditions of pure wet $\mathrm{H}_{2}{ }^{74,77,78}$ and by microstructure optimization (electrode thickness, porosity, buffer layer composition and thickness, current collector,...). Indeed, $A S R$ value of $\sim 0.265 \Omega \mathrm{cm}^{2}$ at $800{ }^{\circ} \mathrm{C}$ was reported for the Ni-free anode $\mathrm{PrBaMn}_{2} \mathrm{O}_{5}$ under pure wet $\mathrm{H}_{2}$ and much lower values for the corresponding Ni-or Coexsolved samples; $A S R \sim 0.099 \Omega \mathrm{cm}^{2}$ for $\mathrm{PrBaMn}_{1.7} \mathrm{Ni}_{0.3} \mathrm{O}_{5}$ at $800{ }^{\circ} \mathrm{C}$ and $A S R \sim 0.167 \Omega$ $\mathrm{cm}^{2}$ for $\mathrm{PrBaMn}_{1.7} \mathrm{Co}_{0.3} \mathrm{O}_{5} .{ }^{25}$ 
Dry reforming of methane (DRM)

Prior to the reaction, the $S$-PBMNx samples were reduced with $\mathrm{H}_{2}$ flow at $800{ }^{\circ} \mathrm{C}$ for $10 \mathrm{~h}$ in the flow reactor. This treatment formed the $R$ - PBMNx samples. The catalytic tests were conducted between 700 and $800{ }^{\circ} \mathrm{C}$ using a mixture of $\mathrm{CO}_{2}: \mathrm{CH}_{4}: \mathrm{N}_{2}=3: 3: 94$ mol\% at a total flow rate of $80 \mathrm{~mL} / \mathrm{min}$ for total exposure of up to $5 \mathrm{~h}$. The performance was evaluated in terms of $\mathrm{CH}_{4}$ molar conversion.

Both $R$-PBMN0 and $R$-PBMN0.05 display insignificant $\mathrm{CH}_{4}$ conversion $(<1 \%)$ with no dependence on reaction temperature. Generally, rare-earth manganite oxides are not active for $\mathrm{CH}_{4}$ reforming but have significant effect as support on the catalytic activity of Ni-based oxides. For instance, $\mathrm{La}_{0.75} \mathrm{Sr}_{0.25} \mathrm{Cr}_{0.5} \mathrm{Mn}_{0.5} \mathrm{O}_{3}$ displays little activity for DRM. ${ }^{79}$

$R$-PBMN0.1 and $R$-PBMN0.2 achieved a $\mathrm{CH}_{4}$ conversion rate of $11 \%$ along with a $\mathrm{CO}_{2}$ conversion of $20 \%$ and $32 \%$ respectively. The production of $\mathrm{H}_{2}$ improved moderately between PBMN0.1 (31\%) and PBMN0.2 (37\%.) The $\mathrm{H}_{2} / \mathrm{CO}$ ratio of 0.4 for PBMN0.1 and 0.6 PBMN0.2 is below the unity due to the simultaneous occurrence of the RWGS reaction (Eq. 2) with DRM (Eq. 1). ${ }^{34,41-44}$ Stable performance of PBMN0.2 at $800{ }^{\circ} \mathrm{C}$ was sustained up to at least 5h, as shown in Fig. 9. Coke deposition was estimated at $0.017 \mathrm{~g} \cdot \mathrm{g}_{\mathrm{cat}}{ }^{-1} \mathrm{~h}^{-1}$ and might occur by $\mathrm{CO}$ disproportionation (Eq. 2) and methane decomposition (Eq. 3). The main results of the $R$-PBMNx samples for DRM are summarized in Table 2 along with relevant data form the literature. 
Table 2. Catalytic tests for $R$-PBMNx in DRM at $800{ }^{\circ} \mathrm{C}$. Results after $5 \mathrm{~h}$ of reaction.

\begin{tabular}{ccccccc}
\hline Catalyst & $\mathrm{CH}_{4}$ Conv. & $\mathrm{CO}_{2}$ Conv. & $\mathrm{H}_{2}$ & $\mathrm{CO}$ & $\mathrm{H}_{2} / \mathrm{CO}$ & $\mathrm{C}$ formed \\
& $\%$ & $\%$ & $\%$ & $\%$ & ratio & $\left(\mathrm{g} \mathrm{g}_{\text {cat }}{ }^{-1} \mathrm{~h}^{-1}\right)$ \\
\hline PBMN0 & $<1$ & $<1$ & 69 & 31 & 2.2 & $\sim 0$ \\
\hline PBMN0.05 & $<1$ & $<1$ & $\sim 0$ & $\sim 0$ & $\sim 0$ & 0.018 \\
\hline PBMN0.1 & 11 & 20 & 31 & 69 & 0.4 & 0.039 \\
\hline PBMN0.2 & 11 & 32 & 37 & 63 & 0.6 & 0.017 \\
\hline
\end{tabular}

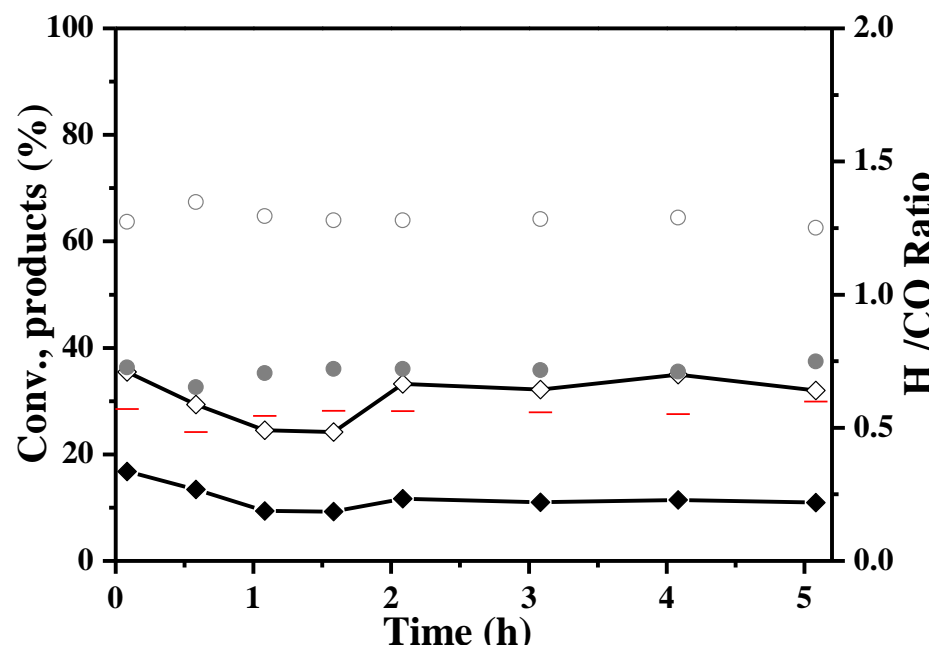

Figure 9. Stability tests on $R$-PBMN0.2 at $800{ }^{\circ} \mathrm{C}_{0} \mathrm{CH}_{4}(\diamond)$ and $\mathrm{CO}_{2}(\diamond)$ conversion and gasphase products; $\mathrm{H}_{2}(\bullet), \mathrm{CO}(\circ)$ and $\mathrm{H}_{2} / \mathrm{CO}$ ratio (-).

A direct comparison with the DRM activity of related with layered perovskites reported in the literature is difficult because the catalytic tests were run at different operating conditions $\left(\mathrm{CH}_{4}: \mathrm{CO}_{2}\right.$ :inert gas ratio, partial pressure of $\mathrm{CH}_{4}$ and $\mathrm{CO}_{2}$, gas flow, mass of catalyst, etc.). Some relevant results listed in Table 3 show that the catalyst performance increases considerably above $800{ }^{\circ} \mathrm{C}$ due to the endothermicity of the DRM reaction. If we compare the performance at $800{ }^{\circ} \mathrm{C}$, we notice that $\mathrm{PrBaMn}_{2} \mathrm{O}_{5+\delta}\left(200 \mathrm{mg}, \mathrm{CO}_{2}: \mathrm{CH}_{4}: \mathrm{He}=20: 20: 60\right.$ $\mathrm{mLmin}^{-1}$ ) enables $1.5 \% \mathrm{CO}_{2}$ while the introduction of nickel in $\mathrm{PrBaMn}_{1.7} \mathrm{Ni}_{0.3} \mathrm{O}_{5+\delta}$ improved the conversion by an order of magnitude. However, the $\mathrm{CO}_{2}$ conversion rate remains unchanged with $\mathrm{Fe}^{3+}$ infiltration. Substitution of $\mathrm{Co}$ ions for $\mathrm{Ni}^{2+}$ resulting in the 
$\operatorname{PrBaMn}_{1.7} \mathrm{Co}_{0.1} \mathrm{Ni}_{0.2} \mathrm{O}_{5+\delta}$ and $\operatorname{PrBaMn}_{1.7} \mathrm{Co}_{0.3} \mathrm{O}_{5+\delta}$ compositions led to reduction of the $\mathrm{CO}_{2}$ conversion rates to $7.5 \%$ and $5 \%$ respectively but the performance of the latter compound could be improved by infiltration of $\mathrm{Fe}^{3+}$ ions. ${ }^{80,81}$

Table 3. Summary of relevant layered of relevant results on double perovskite catalysts $(200 \mathrm{mg})$ on DRM conducted using $\mathrm{CO}_{2}: \mathrm{CH}_{4}: \mathrm{He}=20: 20: 60$ vol\% at a total flow rate of $100 \mathrm{mLmin}^{-1}$ compared with this work $\left(50 \mathrm{mg}\right.$ catalyst, $\mathrm{CO}_{2}: \mathrm{CH}_{4}: \mathrm{He}=3: 3: 94$ vol\%, flow rate $\left.80 \mathrm{mLmin}^{-1}\right)$.

\begin{tabular}{|c|c|c|c|c|}
\hline \multirow[t]{2}{*}{ Catalyst } & \multicolumn{3}{|c|}{$\begin{array}{c}\mathrm{CO}_{2} \text { conversion }(\%) \text { at different } \\
\text { temperature }\left({ }^{\circ} \mathrm{C}\right)\end{array}$} & \multirow[t]{2}{*}{ Ref } \\
\hline & $800^{\circ} \mathrm{C}$ & $850{ }^{\circ} \mathrm{C}$ & $900{ }^{\circ} \mathrm{C}$ & \\
\hline \multirow{3}{*}{$\operatorname{PrBaMn}_{2} \mathrm{O}_{5+\delta}$} & 2.5 & 5 & 10 & 80 \\
\hline & 1.5 & 2.5 & 12.5 & 13 \\
\hline & 1.5 & 2.5 & 7.5 & 52 \\
\hline $\mathrm{PrBaMn}_{1.7} \mathrm{Ni}_{0.3} \mathrm{O}_{5+\delta}$ & 15 & 25 & 42.5 & 13 \\
\hline$R$-PBMN0 & $<1$ & & & \multirow{4}{*}{$\begin{array}{l}\text { This } \\
\text { work }\end{array}$} \\
\hline$R$-PBMN0.05 & $<1$ & & & \\
\hline$R$-PBMN0.1 & 20 & & & \\
\hline$R$-PBMN0.2 & 32 & & & \\
\hline $\begin{array}{c}\operatorname{PrBaMn}_{1.7} \mathrm{Co}_{0.1} \mathrm{Ni}_{.0 .2} \mathrm{O}_{5+\delta} \\
\operatorname{PrBaMn}_{1.7} \mathrm{Ni}_{0.3} \mathrm{O}_{5+\delta}+12 \mathrm{wt} \% \text { Fe infiltration }\end{array}$ & $\begin{array}{l}7.5 \\
15\end{array}$ & $\begin{array}{l}20 \\
28\end{array}$ & $\begin{array}{l}40 \\
45\end{array}$ & 80 \\
\hline $\begin{array}{c}\operatorname{PrBaMn}_{1.7} \mathrm{Co}_{0.3} \mathrm{O}_{5+\delta} \\
\operatorname{PrBaMn}_{1.7} \mathrm{Co}_{0.3} \mathrm{O}_{5+\delta}+12 \mathrm{wt} \% \text { Fe infiltration }\end{array}$ & $\begin{array}{l}2.0 \\
5.0\end{array}$ & $\begin{array}{c}4.0 \\
15.0\end{array}$ & $\begin{array}{l}12.5 \\
30.0\end{array}$ & 52 \\
\hline
\end{tabular}

The mechanism of DRM is detailed by Papadopoulou et $a l .{ }^{82}{ }^{83}$ For Ni-based catalysts on a basic supports, the mechanism follows a bi-functional pathways where $\mathrm{CH}_{4}$ activates on the metal and $\mathrm{CO}_{2}$ activates on the support. The reforming reaction begins via $\mathrm{CH}_{4}$ dissociative adsorption on Ni active sites. The basicity of the support and the presence of oxygen vacancies play a significant role in oxidizing surface carbon. For instance, in $\mathrm{LaNiO}_{3}$ catalyst which has been widely investigated for DRM, the $\mathrm{CO}_{2}$ adsorption with consecutive formation of the intermediate $\mathrm{La}_{2} \mathrm{O}_{3}-\mathrm{CO}_{3}$ species. To summarize, while catalytic activity ${ }^{19,84,85}$ is dictated by the metal particles (size, surface area and dispersion), catalyst resistance to carbon deposition is greatly influenced by the support. ${ }^{12,46}$

\section{Conclusion}


We synthesized a series of $A$-site deficient perovskite manganates $\left(\operatorname{Pr}_{0.5} \mathrm{Ba}_{0.5}\right)_{1-x / 2} \mathrm{Mn}_{1-}$ ${ }_{x / 2} \mathrm{Ni}_{x / 2} \mathrm{O}_{3}$. Under hydrogen atmosphere, nickel exsolution is accompanied by a phase reconstruction of the perovskite substrate. The $\mathrm{Ni}$ nanoparticles improve hydrogen dissociative adsorption (rate-limiting step). The highest $\mathrm{CO}_{2}$ conversion for DRM was obtained for the exsolved sample with the highest Ni content $(x=0.2)$ while no activity was observed for the Ni-free sample (perovskite support). The lack of structure instability of the double perovskite support formed followingNi-exsolution prevents $\mathrm{Ni}$ nanoparticles dissolution into the hot lattice during oxidation.

\section{Acknowledgements}

This work is supported by the PhD grants provided for P. M. from the INSA-MESRI grant from Ministry of Higher Education, of Research and Innovation. X. Liu gratefully acknowledges a grant from China Scholarship Council CSC. We are grateful to L. Joanny (ScanMAT) for the SEM measurements and the helpful discussions.

\section{Uncategorized References}

1. Huang, K.; Goodenough, J. B., 1 - Introduction to solid oxide fuel cells (SOFCs). In Solid Oxide Fuel Cell Technology, Huang, K.; Goodenough, J. B., Eds. Woodhead Publishing: 2009; pp 1-9.

2. McIntosh, S.; Gorte, R. J., Direct Hydrocarbon Solid Oxide Fuel Cells. Chemical Reviews 2004, $104,(10), 4845-4866$.

3. Matsuzaki, Y.; Yasuda, I., The poisoning effect of sulfur-containing impurity gas on a SOFC anode: Part I. Dependence on temperature, time, and impurity concentration. Solid State lonics 2000, 132, (3-4), 261-269.

4. Tonus, F.; Bahout, M.; Dorcet, V.; Gauthier, G. H.; Paofai, S.; Smith, R. I.; Skinner, S. J., Redox behavior of the SOFC electrode candidate NdBaMn2O5+[small delta] investigated by hightemperature in situ neutron diffraction: first characterisation in real time of an LnBaMn2O5.5 intermediate phase. Journal of Materials Chemistry A 2016, 4, (30), 11635-11647.

5. Tonus, F.; Bahout, M.; Dorcet, V.; Sharma, R. K.; Djurado, E.; Paofai, S.; Smith, R. I.; Skinner, S. J., A-site order-disorder in the $\mathrm{NdBaMn2O5+[small} \mathrm{delta]} \mathrm{SOFC} \mathrm{electrode} \mathrm{material} \mathrm{monitored} \mathrm{in} \mathrm{situ}$ by neutron diffraction under hydrogen flow. Journal of Materials Chemistry A 2017, 5, (22), 1107811085. 
6. Pineda, O. L.; Moreno, Z. L.; Roussel, P.; Świerczek, K.; Gauthier, G. H., Synthesis and preliminary study of the double perovskite $\mathrm{NdBaMn} 2 \mathrm{O} 5+\delta$ as symmetric SOFC electrode material. Solid State lonics 2016, 288, 61-67.

7. Sengodan, S.; Choi, S.; Jun, A.; Shin, T. H.; Ju, Y.-W.; Jeong, H. Y.; Shin, J.; Irvine, J. T. S.; Kim, G., Layered oxygen-deficient double perovskite as an efficient and stable anode for direct hydrocarbon solid oxide fuel cells. Nat Mater 2015, 14, (2), 205-209.

8. Wang, W.; Su, C.; Wu, Y.; Ran, R.; Shao, Z., Progress in Solid Oxide Fuel Cells with NickelBased Anodes Operating on Methane and Related Fuels. Chemical Reviews 2013, 113, (10), 81048151.

9. Jardiel, T.; Caldes, M. T.; Moser, F.; Hamon, J.; Gauthier, G.; Joubert, O., New SOFC electrode materials: The Ni-substituted LSCM-based compounds La0.75Sr0.25)(Cr0.5Mn0.5-x Ni-x)O-3 (-) (delta) and (La0.75Sr0.25)(Cr0.5- xNixMn0.5)O-3 (- delta). Solid State lonics 2010, 181, (19-20), 894901.

10. Niu, B.; Jin, F.; Fu, R.; Feng, T.; Shen, Y.; Liu, J.; He, T., Pd-impregnated Sr1.9VMoO6- $\delta$ double perovskite as an efficient and stable anode for solid-oxide fuel cells operating on sulfur-containing syngas. Electrochimica Acta 2018, 274, 91-102.

11. Park, C.; Keane, M. A., Catalyst support effects in the growth of structured carbon from the decomposition of ethylene over nickel. Journal of Catalysis 2004, 221, (2), 386-399.

12. Pakhare, D.; Spivey, J., A review of dry (CO2) reforming of methane over noble metal catalysts. Chemical Society Reviews 2014, 43, (22), 7813-7837.

13. Joo, S.; Kwon, O.; Kim, S.; Jeong, H. Y.; Kim, G., Ni-Fe Bimetallic Nanocatalysts Produced by Topotactic Exsolution in Fe deposited PrBaMn1.7Ni0.305 $+\delta$ for Dry Reforming of Methane. Journal of The Electrochemical Society 2020, 167, (6), 064518.

14. Neagu, D.; Papaioannou, E. I.; Ramli, W. K. W.; Miller, D. N.; Murdoch, B. J.; Ménard, H.; Umar, A.; Barlow, A. J.; Cumpson, P. J.; Irvine, J. T. S.; Metcalfe, I. S., Demonstration of chemistry at a point through restructuring and catalytic activation at anchored nanoparticles. Nature Communications 2017, 8, (1), 1855.

15. Myung, J.-h.; Neagu, D.; Miller, D. N.; Irvine, J. T. S., Switching on electrocatalytic activity in solid oxide cells. Nature 2016, 537, (7621), 528-531.

16. Neagu, D.; Oh, T.-S.; Miller, D. N.; Ménard, H.; Bukhari, S. M.; Gamble, S. R.; Gorte, R. J.; Vohs, J. M.; Irvine, J. T. S., Nano-socketed nickel particles with enhanced coking resistance grown in situ by redox exsolution. Nature Communications 2015, 6, 8120.

17. Vecino-Mantilla, S.; Gauthier-Maradei, P.; Huvé, M.; Serra, J. M.; Roussel, P.; Gauthier, G. H., Nickel Exsolution-Driven Phase Transformation from an $n=2$ to an $n=1$ Ruddlesden-Popper Manganite for Methane Steam Reforming Reaction in SOFC Conditions. ChemCatChem 2019, 11, (18), 46314641.

18. Joo, S.; Seong, A.; Kwon, O.; Kim, K.; Lee, J. H.; Gorte, R. J.; Vohs, J. M.; Han, J. W.; Kim, G., Highly active dry methane reforming catalysts with boosted in situ grown Ni-Fe nanoparticles on perovskite via atomic layer deposition. Science Advances 2020, 6, (35), eabb1573.

19. Mortensen, P. M.; Dybkjær, I., Industrial scale experience on steam reforming of CO2-rich gas. Applied Catalysis A: General 2015, 495, 141-151.

20. Hou, N.; Yao, T.; Li, P.; Yao, X.; Gan, T.; Fan, L.; Wang, J.; Zhi, X.; Zhao, Y.; Li, Y., A-Site Ordered Double Perovskite with in Situ Exsolved Core-Shell Nanoparticles as Anode for Solid Oxide Fuel Cells. ACS Applied Materials \& Interfaces 2019, 11, (7), 6995-7005.

21. Bahout, M.; Managutti, P. B.; Dorcet, V.; Le Gal La Salle, A.; Paofai, S.; Hansen, T. C., In situ exsolution of $\mathrm{Ni}$ particles on the PrBaMn2O5 SOFC electrode material monitored by high temperature neutron powder diffraction under hydrogen. Journal of Materials Chemistry $A$ 2020, 8, (7), 3590-3597.

22. Ohhun, K.; Sangwook, J.; Sihyuk, C.; Sivaprakash, S.; Guntae, K., Review on exsolution and its driving forces in perovskites. Journal of Physics: Energy 2020. 
23. Du, Z.; Zhao, H.; Yi, S.; Xia, Q.; Gong, Y.; Zhang, Y.; Cheng, X.; Li, Y.; Gu, L.; Świerczek, K., HighPerformance Anode Material Sr2FeMo0.65Ni0.35O6- $\delta$ with In Situ Exsolved Nanoparticle Catalyst. ACS Nano 2016, 10, (9), 8660-8669.

24. Takehira, K., Highly Dispersed and Stable Supported Metal Catalysts Prepared by Solid Phase Crystallization Method. Catalysis Surveys from Asia 2002, 6, (1), 19-32.

25. Kwon, O.; Sengodan, S.; Kim, K.; Kim, G.; Jeong, H. Y.; Shin, J.; Ju, Y.-W.; Han, J. W.; Kim, G., Exsolution trends and co-segregation aspects of self-grown catalyst nanoparticles in perovskites. Nature Communications 2017, 8, 15967.

26. Sun, Y.-F.; Zhang, Y.-Q.; Hua, B.; Behnamian, Y.; Li, J.; Cui, S.-H.; Li, J.-H.; Luo, J.-L., Molybdenum doped PrO.5Ba0.5MnO3- $\delta$ (Mo-PBMO) double perovskite as a potential solid oxide fuel cell anode material. Journal of Power Sources 2016, 301, 237-241.

27. Zhu, J.; Zhang, W.; Li, Y.; Yue, W.; Geng, G.; Yu, B., Enhancing CO2 catalytic activation and direct electroreduction on in-situ exsolved $\mathrm{Fe} / \mathrm{MnOx}$ nanoparticles from ( $\mathrm{Pr}, \mathrm{Ba}) 2 \mathrm{Mn} 2-\mathrm{yFeyO}+\delta$ layered perovskites for SOEC cathodes. Applied Catalysis B: Environmental 2020, 268, 118389.

28. Sun, Y.-F.; Li, J.-H.; Cui, L.; Hua, B.; Cui, S.-H.; Li, J.; Luo, J.-L., A-site-deficiency facilitated in situ growth of bimetallic Ni-Fe nano-alloys: a novel coking-tolerant fuel cell anode catalyst. Nanoscale 2015, 7, (25), 11173-11181.

29. Sun, Y.-F.; Li, J.-H.; Wang, M.-N.; Hua, B.; Li, J.; Luo, J.-L., A-site deficient chromite perovskite with in situ exsolution of nano-Fe: a promising bi-functional catalyst bridging the growth of CNTs and SOFCs. Journal of Materials Chemistry A 2015, 3, (28), 14625-14630.

30. Sun, Y.; Li, J.; Zeng, Y.; Amirkhiz, B. S.; Wang, M.; Behnamian, Y.; Luo, J., A-site deficient perovskite: the parent for in situ exsolution of highly active, regenerable nano-particles as SOFC anodes. Journal of Materials Chemistry A 2015, 3, (20), 11048-11056.

31. Neagu, D.; Tsekouras, G.; Miller, D. N.; Ménard, H.; Irvine, J. T. S., In situ growth of nanoparticles through control of non-stoichiometry. Nature Chemistry 2013, 5, 916.

32. Hua, B.; Li, M.; Sun, Y.-F.; Zhang, Y.-Q.; Yan, N.; Chen, J.; Thundat, T.; Li, J.; Luo, J.-L., A coupling for success: Controlled growth of $\mathrm{Co} / \mathrm{CoOx}$ nanoshoots on perovskite mesoporous nanofibres as high-performance trifunctional electrocatalysts in alkaline condition. Nano Energy 2017, 32, 247-254.

33. Kobsiriphat, W.; Madsen, B. D.; Wang, Y.; Shah, M.; Marks, L. D.; Barnett, S. A., Nickel- and Ruthenium-Doped Lanthanum Chromite Anodes: Effects of Nanoscale Metal Precipitation on Solid Oxide Fuel Cell Performance. Journal of The Electrochemical Society 2010, 157, (2), B279.

34. Jang, W.-J.; Shim, J.-O.; Kim, H.-M.; Yoo, S.-Y.; Roh, H.-S., A review on dry reforming of methane in aspect of catalytic properties. Catalysis Today 2019, 324, 15-26.

35. Yan, X.; Hu, T.; Liu, P.; Li, S.; Zhao, B.; Zhang, Q.; Jiao, W.; Chen, S.; Wang, P.; Lu, J.; Fan, L.; Deng, X.; Pan, Y.-X., Highly efficient and stable Ni/CeO2-SiO2 catalyst for dry reforming of methane: Effect of interfacial structure of $\mathrm{Ni} / \mathrm{CeO} 2$ on SiO2. Applied Catalysis B: Environmental 2019, 246, 221231.

36. Das, S.; Ashok, J.; Bian, Z.; Dewangan, N.; Wai, M. H.; Du, Y.; Borgna, A.; Hidajat, K.; Kawi, S., Silica-Ceria sandwiched $\mathrm{Ni}$ core-shell catalyst for low temperature dry reforming of biogas: Coke resistance and mechanistic insights. Applied Catalysis B: Environmental 2018, 230, 220-236.

37. Wang, F.; Han, B.; Zhang, L.; Xu, L.; Yu, H.; Shi, W., CO2 reforming with methane over smallsized Ni@SiO2 catalysts with unique features of sintering-free and low carbon. Applied Catalysis B: Environmental 2018, 235, 26-35.

38. Li, M.; van Veen, A. C., Tuning the catalytic performance of Ni-catalysed dry reforming of methane and carbon deposition via Ni-CeO2-x interaction. Applied Catalysis B: Environmental 2018, 237, 641-648.

39. Liu, Z.; Lustemberg, P.; Gutiérrez, R. A.; Carey, J. J.; Palomino, R. M.; Vorokhta, M.; Grinter, D. C.; Ramírez, P. J.; Matolín, V.; Nolan, M.; Ganduglia-Pirovano, M. V.; Senanayake, S. D.; Rodriguez, J. A., In Situ Investigation of Methane Dry Reforming on Metal/Ceria(111) Surfaces: Metal-Support Interactions and C-H Bond Activation at Low Temperature. 2017, 56, (42), 13041-13046. 
40. Löfberg, A.; Guerrero-Caballero, J.; Kane, T.; Rubbens, A.; Jalowiecki-Duhamel, L., Ni/CeO2 based catalysts as oxygen vectors for the chemical looping dry reforming of methane for syngas production. Applied Catalysis B: Environmental 2017, 212, 159-174.

41. Abdulrasheed, A.; Jalil, A. A.; Gambo, Y.; Ibrahim, M.; Hambali, H. U.; Shahul Hamid, M. Y., A review on catalyst development for dry reforming of methane to syngas: Recent advances. Renewable and Sustainable Energy Reviews 2019, 108, 175-193.

42. Aramouni, N. A. K.; Touma, J. G.; Tarboush, B. A.; Zeaiter, J.; Ahmad, M. N., Catalyst design for dry reforming of methane: Analysis review. Renewable and Sustainable Energy Reviews 2018, 82, 2570-2585.

43. Gao, Y.; Jiang, J.; Meng, Y.; Yan, F.; Aihemaiti, A., A review of recent developments in hydrogen production via biogas dry reforming. Energy Conversion and Management 2018, 171, 133155.

44. Zhang, G.; Liu, J.; Xu, Y.; Sun, Y., A review of $\mathrm{CH} 4 \mathrm{CO} 2$ reforming to synthesis gas over Ni-based catalysts in recent years (2010-2017). International Journal of Hydrogen Energy 2018, 43, (32), 15030-15054.

45. Seo, H. O., Recent Scientific Progress on Developing Supported Ni Catalysts for Dry (CO2) Reforming of Methane. 2018, 8, (3), 110.

46. Usman, M.; Wan Daud, W. M. A.; Abbas, H. F., Dry reforming of methane: Influence of process parameters-A review. Renewable and Sustainable Energy Reviews 2015, 45, 710-744.

47. Hubert, M.; Laurencin, J.; Cloetens, P.; Mougin, J.; Ferreira Sanchez, D.; Pylypko, S.; Morales, M.; Morata, A.; Morel, B.; Montinaro, D.; Siebert, E.; Lefebvre-Joud, F., Solid Oxide Cell Degradation Operated in Fuel Cell and Electrolysis Modes: A Comparative Study on Ni Agglomeration and LSCF Destabilization. ECS Transactions 2017, 78, (1), 3167-3177.

48. Yu, X.; Wang, N.; Chu, W.; Liu, M., Carbon dioxide reforming of methane for syngas production over La-promoted NiMgAl catalysts derived from hydrotalcites. Chemical Engineering Journal 2012, 209, 623-632.

49. Wei, J.-M.; Xu, B.-Q.; Li, J.-L.; Cheng, Z.-X.; Zhu, Q.-M., Highly active and stable Ni/ZrO2 catalyst for syngas production by CO2 reforming of methane. Applied Catalysis A: General 2000, 196, (2), L167-L172.

50. Xu, G.; Ma, H.; Zhong, M.; Zhou, J.; Yue, Y.; He, Z., Influence of pH on characteristics of BaFe12O19 powder prepared by sol-gel auto-combustion. Journal of Magnetism and Magnetic Materials 2006, 301, (2), 383-388.

51. Roisnel, T.; Rodriguez-Carvajal, J., WinPLOTR: A Windows tool for powder diffraction pattern analysis. In Epdic 7: European Powder Diffraction, Pts 1 and 2, Delhez, R.; Mittemeijer, E. J., Eds. 2001; Vol. 378-3, pp 118-123.

52. Joo, S.; Kwon, O.; Kim, K.; Kim, S.; Kim, H.; Shin, J.; Jeong, H. Y.; Sengodan, S.; Han, J. W.; Kim, G., Cation-swapped homogeneous nanoparticles in perovskite oxides for high power density. Nature Communications 2019, 10, (1), 697.

53. Briois, V.; Fonda, E.; Belin, S.; Barthe, L.; La Fontaine, C.; Langlois, F.; Ribbens, M.; Villain, F., SAMBA: The 4-40 keV X-ray absorption spectroscopy beamline at SOLEIL. UVX 2010 - 10e Colloque sur les Sources Cohérentes et Incohérentes UV, VUV et $X$; Applications et Développements Récents 2011, 41-47.

54. Huang, Q.-A.; Hui, S. R.; Wang, B.; Zhang, J., A review of AC impedance modeling and validation in SOFC diagnosis. Electrochimica Acta 2007, 52, 8144-8164.

55. Klotz, D.; Weber, A.; Ivers-Tiffée, E., Practical Guidelines for Reliable Electrochemical Characterization of Solid Oxide Fuel Cells. Electrochimica Acta 2017, 227, 110-126.

56. Patterson, A. L., The Scherrer Formula for X-Ray Particle Size Determination. Physical Review 1939, 56, (10), 978-982.

57. Sengodan, S.; Ju, Y.-W.; Kwon, O.; Jun, A.; Jeong, H. Y.; Ishihara, T.; Shin, J.; Kim, G., SelfDecorated MnO Nanoparticles on Double Perovskite Solid Oxide Fuel Cell Anode by in Situ Exsolution. ACS Sustainable Chemistry \& Engineering 2017, 5, (10), 9207-9213. 
58. Tanaka, H.; Taniguchi, M.; Uenishi, M.; Kajita, N.; Tan, I.; Nishihata, Y.; Mizuki, J. i.; Narita, K.; Kimura, M.; Kaneko, K., Self-Regenerating Rh- and Pt-Based Perovskite Catalysts for AutomotiveEmissions Control. 2006, 45, (36), 5998-6002.

59. He, J.-J.; Wang, C.-X.; Zheng, T.-T.; Zhao, Y.-K., Thermally Induced Deactivation and the Corresponding Strategies for Improving Durability in Automotive Three-Way Catalysts. Johnson Matthey Technology Review 2016, 60, (3), 196-203.

60. Lai, K.-Y.; Manthiram, A., Evolution of Exsolved Nanoparticles on a Perovskite Oxide Surface during a Redox Process. Chemistry of Materials 2018, 30, (8), 2838-2847.

61. Broux, T.; Bahout, M.; Hanlon, J. M.; Hernandez, O.; Paofai, S.; Berenov, A.; Skinner, S. J., High temperature structural stability, electrical properties and chemical reactivity of $\mathrm{NdBaCo}-\mathrm{xMnxO}+\delta$ $(0 \leq x \leq 2)$ perovskites for use as cathode in Solid Oxide Fuel Cells

Journal of Materials Chemistry A 2014, 2, (40), 17015-17023.

62. Burriel, M.; Peña-Martínez, J.; Chater, R. J.; Fearn, S.; Berenov, A. V.; Skinner, S. J.; Kilner, J. A., Anisotropic Oxygen Ion Diffusion in Layered PrBaCo2O5+ $\delta$. Chemistry of Materials 2012, 24, (3), 613-621.

63. Cox-Galhotra, R. A.; Huq, A.; Hodges, J. P.; Yu, C.; Wang, X.; Gong, W.; Jacobson, A. J.; McIntosh, S., An in-situ neutron diffraction study of the crystal structure of $\operatorname{PrBaCo} 2 \mathrm{O} 5+\delta$ at high temperature and controlled oxygen partial pressure. Solid State lonics 2013, 249-250, 34-40.

64. Dong, G.; Yang, C.; He, F.; Jiang, Y.; Ren, C.; Gan, Y.; Lee, M.; Xue, X., Tin doped PrBaFe2O5+ $\delta$ anode material for solid oxide fuel cells. RSC Advances 2017, 7, (37), 22649-22661.

65. Jiang, S. P.; Chen, X. J.; Chan, S. H.; Kwok, J. T.; Khor, K. A., (La0.75Sr0.25)(Cr0.5Mn0.5)O3/YSZ composite anodes for methane oxidation reaction in solid oxide fuel cells. Solid State lonics 2006, $177,(1), 149-157$.

66. Boukamp, B. A., Electrochemical impedance spectroscopy in solid state ionics: recent advances. Solid State lonics 2004, 169, (1), 65-73.

67. Cole, K. S.; Cole, R. H., Dispersion and Absorption in Dielectrics I. Alternating Current Characteristics. J. Chem. Phys. 1941, 9, (4), 341-351.

68. MacDonald, J. R. J. W.-I., John Wiley; Sons, Impedence Spectroscopy--Emphasizing Solid Materials and Systems. 1987, 1-346.

69. Harrington, D. A., The rate-determining step in electrochemical impedance spectroscopy. Journal of Electroanalytical Chemistry 2015, 737, 30-36.

70. Leonide, A.; Sonn, V.; Weber, A.; Ivers-Tiffée, E., Evaluation and Modeling of the Cell Resistance in Anode-Supported Solid Oxide Fuel Cells. Journal of The Electrochemical Society 2007, 155, B36-B41.

71. Primdahl, S., Gas Diffusion Impedance in Characterization of Solid Oxide Fuel Cell Anodes. Journal of The Electrochemical Society 1999, 146, (8), 2827.

72. He, W.; Zou, J.; Wang, B.; Vilayurganapathy, S.; Zhou, M.; Lin, X.; Zhang, K. H. L.; Lin, J.; Xu, P.; Dickerson, J. H., Gas transport in porous electrodes of solid oxide fuel cells: A review on diffusion and diffusivity measurement. Journal of Power Sources 2013, 237, 64-73.

73. Montinaro, D.; Contino, A. R.; Dellai, A.; Rolland, M., Determination of the impedance contributions in anode supported solid oxide fuel cells with $(\mathrm{La}, \mathrm{Sr})(\mathrm{Co}, \mathrm{Fe}) \mathrm{O} 3-\delta$ cathode. International Journal of Hydrogen Energy 2014, 39, (36), 21638-21646.

74. Meng, X.; Wang, Y.; Zhao, Y.; Zhang, T.; Yu, N.; Chen, X.; Miao, M.; Liu, T., In-situ exsolution of nanoparticles from $\mathrm{Ni}$ substituted $\mathrm{S} 2 \mathrm{Fe} 1.5 \mathrm{Mo0} .5 \mathrm{O} 6$ perovskite oxides with different $\mathrm{Ni}$ doping contents. Electrochimica Acta 2020, 348, 136351.

75. Fu, Q. X.; Tietz, F.; Stöver, D., La[sub 0.4]Sr[sub 0.6]Ti[sub 1-x]Mn[sub x]O[sub 3-ס] Perovskites as Anode Materials for Solid Oxide Fuel Cells. Journal of The Electrochemical Society 2006, 153, (4), D74.

76. Gao, Y.; Chen, D.; Saccoccio, M.; Lu, Z.; Ciucci, F., From material design to mechanism study: Nanoscale $\mathrm{Ni}$ exsolution on a highly active A-site deficient anode material for solid oxide fuel cells. Nano Energy 2016, 27, 499-508. 
77. Liu, Z.; Zhou, M.; Chen, M.; Cao, D.; Shao, J.; Liu, M.; Liu, J., A high-performance intermediateto-low temperature protonic ceramic fuel cell with in-situ exsolved nickel nanoparticles in the anode. Ceramics International 2020.

78. Zhu, T.; Troiani, H. E.; Mogni, L. V.; Han, M.; Barnett, S. A., Ni-Substituted Sr(Ti,Fe)O3 SOFC Anodes: Achieving High Performance via Metal Alloy Nanoparticle Exsolution. Joule 2018, 2, (3), 478496.

79. Tao; Irvine, J. T. S.; Plint, S. M., Methane Oxidation at Redox Stable Fuel Cell Electrode La0.75Sr0.25Cr0.5Mn0.503- $\delta$. The Journal of Physical Chemistry B 2006, 110, (43), 21771-21776.

80. Kwon, O.; Kim, K.; Joo, S.; Jeong, H. Y.; Shin, J.; Han, J. W.; Sengodan, S.; Kim, G., Selfassembled alloy nanoparticles in a layered double perovskite as a fuel oxidation catalyst for solid oxide fuel cells. Journal of Materials Chemistry A 2018, 6, (33), 15947-15953.

81. Joo, S.; Kwon, O.; Kim, K.; Kim, S.; Kim, H.; Shin, J.; Jeong, H. Y.; Sengodan, S.; Han, J. W.; Kim, G., Cation-swapped homogeneous nanoparticles in perovskite oxides for high power density. Nat Commun 2019, 10, (1), 697.

82. Papadopoulou, C.; Matralis, H.; Verykios, X., Utilization of Biogas as a Renewable Carbon Source: Dry Reforming of Methane. In Catalysis for Alternative Energy Generation, Guczi, L.; Erdôhelyi, A., Eds. Springer New York: New York, NY, 2012; pp 57-127.

83. Özkara-Aydınoğlu, Ş.; Özensoy, E.; Aksoylu, A. E., The effect of impregnation strategy on methane dry reforming activity of Ce promoted Pt/ZrO2. International Journal of Hydrogen Energy 2009, 34, (24), 9711-9722.

84. Rostrup-Nielsen, J. R.; Sehested, J.; Nørskov, J. K., Hydrogen and synthesis gas by steam- and C02 reforming. In Advances in Catalysis, Academic Press: 2002; Vol. 47, pp 65-139.

85. Borowiecki, T., Nickel catalysts for steam reforming of hydrocarbons; size of crystallites and resistance to coking. Applied Catalysis 1982, 4, (3), 223-231. 